Portland State University

PDXScholar

11-29-1995

\title{
An Analysis of Oregon Department of Transportation Planned Highway Construction Projects for Selected Years from 1978 to 1992
}

Glen A. Fleming

Portland State University

Follow this and additional works at: https://pdxscholar.library.pdx.edu/open_access_etds

Part of the Geography Commons

Let us know how access to this document benefits you.

Recommended Citation

Fleming, Glen A., "An Analysis of Oregon Department of Transportation Planned Highway Construction Projects for Selected Years from 1978 to 1992" (1995). Dissertations and Theses. Paper 5071.

https://doi.org/10.15760/etd.6947

This Thesis is brought to you for free and open access. It has been accepted for inclusion in Dissertations and Theses by an authorized administrator of PDXScholar. Please contact us if we can make this document more accessible: pdxscholar@pdx.edu. 
THESIS APPROVAL

The abstract and thesis of Glen A. Fleming for the Master of Science in Geography, were presented November 29,1995 , and accepted by the thesis committee and the department.

COMMITTEE APPROVALS:

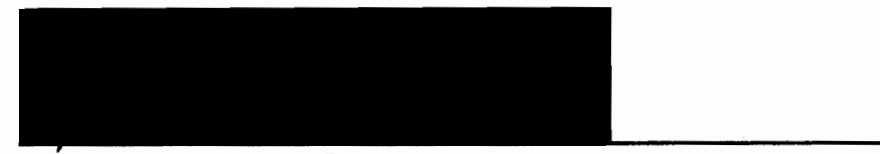

Kenneth Dueker, Chair

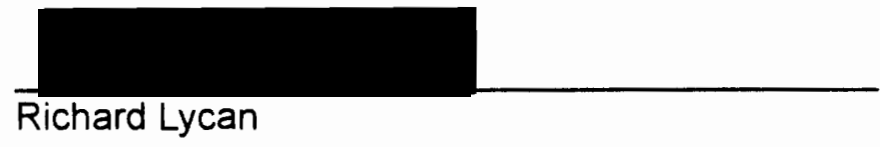

DEPARTMENT APPROVAL:

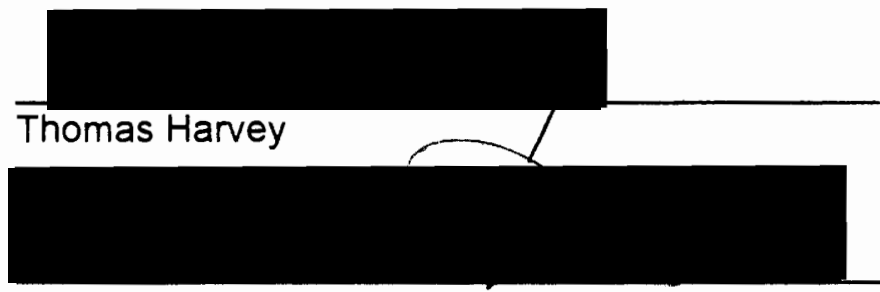

William Rabiega

Representative of the Office of Graduate Studies

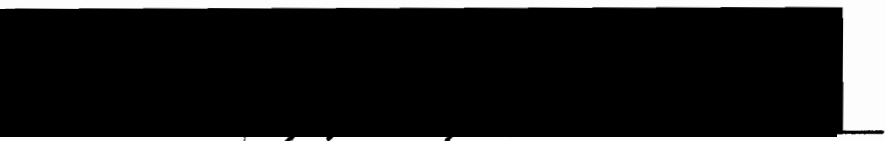

Daniel Johnsoh, Chair

Department of Geography

ACCEPTED FOR PORTLAND STATE UNIVERSITY BY THE LIBRARY

by on

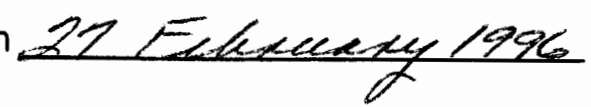




\section{ABSTRACT}

An abstract of the thesis of Glen A. Fleming for the Master of Science in Geography presented November 29, 1995.

Title: An Analysis of Oregon Department of Transportation Planned Highway

Construction Projects for Selected Years From 1978 to 1992.

Construction of highway projects is one of the most important and expensive state government functions. Highway construction projects bring revenue and jobs to the locales in which they are built, in addition to providing a better transportation infrastructure within or between communities, states or nations.

In the state of Oregon, its Department of Transportation (ODOT) publishes a document forecasting planned highway construction expenditures for the next six years. This document was called, until recently the six-year highway program; it is the Department's primary programming document for planned highway construction expenditures in the next six years, with updates every two years. More recently the document has been renamed the Statewide Transportation Improvement Program (STIP).

The purpose of this study was to examine the distribution of planned highway construction projects within the state of Oregon from 1978 to 1992 by analyzing five selected ODOT six-year programs. Planned highway project expenditures were analyzed statistically, by county, to explain patterns of expenditure by project location, work type, highway level of importance, and changes in these over time. To analyze 
the significance of proposed highway expenditures by county, the cost of highway projects was compared and statistically measured against county factors such as population, area, total state highway mileage, and vehicle miles traveled (VMT). Data was collected from ODOT, the Oregon Secretary of State and the Center for Population Research and Census. Analysis consisted of simple grouping and sorting by program year, work type, etc., bivariate linear regression, and multiple linear regression. These analyses were performed on individual project data, and project data aggregated to the county level, for each of the five selected ODOT programs.

The analyses determined that there was a positive correlation between relatively high programmed highway expenditures, large county populations (and population densities) and high total highway mileages per county in Oregon; in other words, the highway funds went where the people and state highways were. Furthermore, the analysis confirmed relative ranking hypotheses between highway expenditures work types, and the type of highway (LOI) the projects were to be performed on. These two secondary "ranking by type" hypotheses were: 1.) project work type, from most to least expensive: modernization, bridge, preservation, safety, and miscellaneous; 2.) LOI, from highest to least importance: interstate, statewide, regional, and statewide.

Observations on the trends of expenditures over time showed that 1.) modernization expenditures in Oregon increased from 1978 to 1988 , then declined in 1992 when preservation projects increased; and that 2.) interstate highways in Oregon received the highest funding overall from 1978 to 1988 , but that from 1986 onward, statewide highways received more and more funding, and by 1992 were receiving more funding than the interstates. 


\author{
AN ANALYSIS OF \\ OREGON DEPARTMENT OF TRANSPORTATION \\ PLANNED HIGHWAY CONSTRUCTION PROJECTS \\ FOR SELECTED YEARS FROM 1978 TO 1992
}

by

GLEN A. FLEMING

A thesis submitted in partial fulfillment of the requirements for the degree of

\author{
MASTER OF SCIENCE \\ in \\ GEOGRAPHY
}

Portland State University 


\section{PAGE}

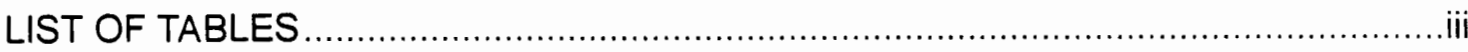

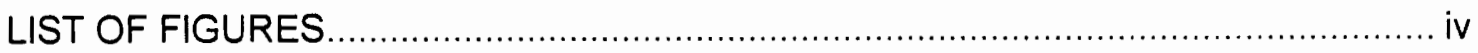

STUDY OBJECTIVE

INTRODUCTION

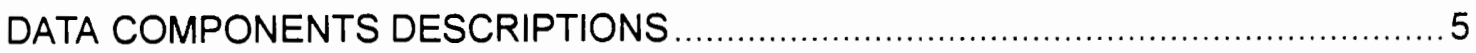

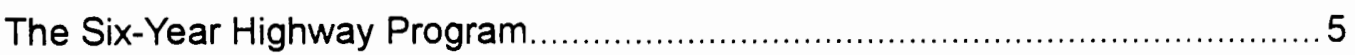

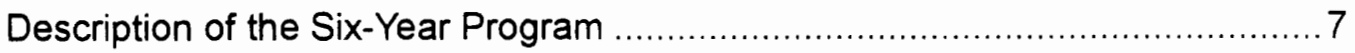

County Area, Population, Vehicle Miles Traveled (VMT), and Income Data ...... 10

ODOT's Level of Importance (LOI) Highway Classification System..................12

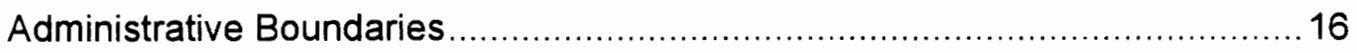

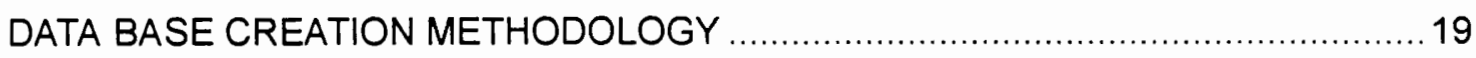

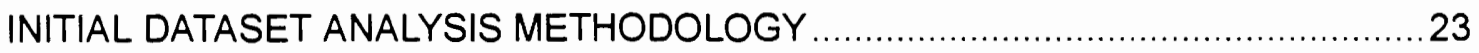

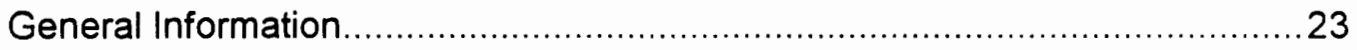

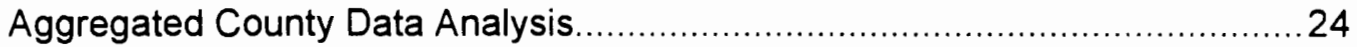

Aggregated County Dataset Multiple Regression Analysis ..............................35

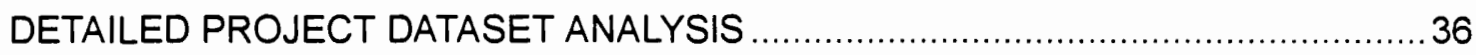

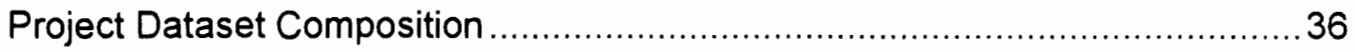

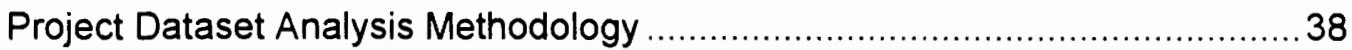

Revised County Dataset Multiple Regression Analysis .................................45

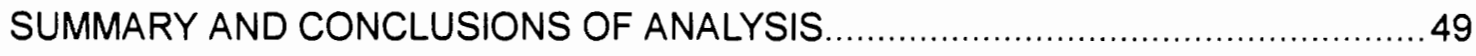


Summary 49

Conclusion. 50

REFERENCES 52 APPENDICES

A COUNTY DATASET PRINTOUTS 1978 THROUGH 1992 .55

B SAMPLE PROJECT DATASET, 1988 61 


\section{LIST OF TABLES}

TABLE

PAGE

1 Oregon Highway Mileages by County and Level of Importance, with

Land Area (Sq. Mi.) by County. 11

II Oregon Population by County. 13

III Oregon Vehicle Miles Traveled by County 14

IV 1988 Project Cost per Mile per Mile per Square Mile by County.. 32

V County Dataset Linear Regression Results. 34

VI Project Dataset Multiple Regression Results. 42

VII County Dataset Multiple Regression Results. 46 


\section{LIST OF FIGURES}

FIGURE

PAGE

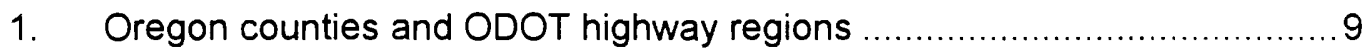

2. Oregon highway levels of importance (LOI) ................................... 17

3. Planned ODOT expenditures by work type and program ......................25

4. Planned ODOT expenditures by work type and program, percentages .... 26

5. Planned ODOT expenditures by highway

level of importanace (LOI) and Program

6. Planned ODOT expenditures by highway

level of importanace (LOI) and Program, percentages

7. Cost per mile per mile of highway per square mile

by county, total highways 33 


\section{STUDY OBJECTIVE}

This study analyzes the distribution of planned highway construction projects within the state of Oregon by its Oregon Department of Transportation (ODOT) by type, year and location. Proposed highway expenditures are analyzed statistically to explain patterns of highway expenditures by county. Variation in project level expenditures are analyzed to explain the influence of type of roadway project and highway level of importance. The objective of the study is to determine the major significant factors, such as population, area or highway mileage, which influence the distribution of highway expenditures. A secondary objective of this study is to determine the priorities of ODOT highway construction projects concerning project type and highway classification types, and how those priorities have changed from 1978 to 1992. 


\section{INTRODUCTION}

This project is a study of selected Oregon Department of Transportation (ODOT) Six-Year Highway Programs, specifically the study of proposed highway construction projects put forward in these programs. All highway construction projects were taken from the five selected Programs and condensed into a tabular spreadsheet format. Other data used in the analysis consisted of state population, vehicle miles traveled (VMT) and per capita income by county and year for each of the selected Program years. County area and length of highway by type per county were held as constants throughout the study period.

The analysis examined correlation between proposed highway construction expenditures per program year and total county highway miles, county area, county population, and county (VMT) to develop insights and relationships. For example, if a county has either high population or highway mileage, then consistently high levels of proposed highway expenditures for that county was expected. Two other relationships were examined: the first quantifies the extent to which some types of construction projects are consistently more expensive than others; and second that ODOT's ranking of highways by functional importance explains the relative cost of proposed projects.

A search of pertinent literature over the last fifteen years revealed little concerning the distribution of highway expenditures within a state by project type or location. The two

documents which came closest to explaining a statewide distribution of highway construction projects (expenditures) were the 1987 American Association of State Highway and Transportation Officials (AASHTO) publication "Local Finance Study "and the 1992 
ODOT internal memo 1992 County Equity Study". The AASHTO publication consisted of the summarization and tabulation of nine questions asked by AASHTO of the fifty state Departments of Transportation. This study dealt primarily with how revenues were raised at the state and local level, and how the revenues were distributed between state and local jurisdictions; it did not deal with the statewide distribution of planned construction funds. This report did, however, ask the various states how they distributed state collected revenues to the counties; the primary factors affecting distribution were mileage, vehicle registrations, population and area (AASHTO, 1987).

The ODOT study consisted of four data tables: one was a short tabulation of selected statistics for ten counties; the other three were comparisons of contributions (federal and state fees and taxes paid, such as fuel, excise and weight-mile taxes and permit and registration fees) to benefits (ODOT expenditures and allocations) in various combinations by county. The results of the study found $30 \%$ of the counties paid in equal to what they received back, $30 \%$ received less than paid in and $40 \%$ received more than paid in. It also found that urban counties received $55 \%$ of all expenditures, while paying in $64 \%$ of all taxes and fees. The ratio of payments received to taxes paid was $\$ 0.87$ for urban counties and $\$ 1.23$ for rural counties (ODOT, 1992a).

The results of the 1992 ODOT survey were interesting, but not pertinent to this particular project, since the expenditures from the state were actual amounts spent and included indirect costs such as administration, overhead, usual maintenance activities, and debt service. The 1992 study did not relate to planned construction projects, and was seeking to determine a funding input/output for each county. The 1992 ODOT study mentioned previous studies, but also said there was not any way to directly compare them due to use of different measures and fiscal or calendar years (ODOT, 1992a). Copies of 
the earlier reports were not available, while the personnel who prepared them were primarily temporary employees, or had moved out of the agency. Overall, the 1992 study did not seek to use the same measures of evaluation as this study, and in particular included only actual ODOT expenditures, making no differentiation between construction and maintenance/operations expenditures.

Other than the AASHTO report and the ODOT studies which focused on distribution of state collected road user fees to states and local jurisdictions, there is a dearth of studies on the distribution of funds for the construction of state highways via the capital improvement programming process. There appears to be little study of the process that has evolved over a long period of years, although the research will show there appears to be some equity in the process in terms of equal distribution to population. 


\section{DATA COMPONENT DESCRIPTIONS}

\section{The Six-Year Highway Program}

The first Six-Year Program, approved by the Oregon Transportation Commission (OTC) in May, 1975, was the result of a requirement of the first Oregon Action Plan for Transportation published in 1974. The Six-Year Program was one element of the Oregon Action Plan, and for its editions through 1990, was primarily focused on highway projects. The Oregon Action Plan detailed the system planning, programming and project development process for highway and other transportation projects statewide (ODOT, 1974).

Planning activities of the Action Plan, last revised in 1989 (ODOT, 1989), called for publication of statewide, multimodal, and long term plans, plus more specific modal and regional plans. It was not until 1992, despite the mandate for multimodal planning, that the publication occurred of the first actual statewide multimodal plan, the Oregon Transportation Plan (ODOT, 1992b). The first modal plan, the 1985 Oregon Highway Plan (ODOT, 1985), was republished in 1991 (ODOT, 1991b) and is scheduled for revision in late 1996. Other modal plans have been, and will be published in the future; these include, but are not limited to, the rail (passenger and freight), aeronautics, public transit, and pedestrian/bicycle programs. This study is solely concerned with highway plans, programs and projects. Project development primarily includes engineering and design of projects, not planning, and is not further considered in this study.

This study concerns itself with the programming element called for in the Action Plan; the programming element for Oregon's highway projects is the Six-Year Highway 
Improvement Program - HIP (from 1975 through 1991, subsequently renamed as the Statewide Transportation Improvement Program - STIP). Programming is the process of setting priorities for highway projects identified at local and statewide levels in the planning process. Briefly, Oregon's programming process follows these steps:

1.) develop ranking criteria and procedures (technical ranking, work types, policy, fiscal constraints, geographic areas) by various section and regional managers within ODOT;

2.) project identification from staff, the public and local jurisdictions at a regional level;

3.) project categorization, rough costs and time frame at a regional level;

4.) project prioritization by work type at the regional level;

5.) development of a statewide preliminary six-year program;

6.) public review and comment on the preliminary program;

7.) revision of the public review program to a proposed program;

8.) presentation and approval of the final program by the OTC (ODOT, 1991a).

The Six-Year Program has been through twelve editions, with work beginning on the thirteenth. All of the Six-Year Programs described in this presentation will be called by their publication year, and abbreviated to Program", such as the 1992 Program. Prior to the 1993-98 Six-Year Program (called the 1992 Program in this report), these programs only dealt with planned highway projects (thus the name HIP), receiving state or federal funding; the last three reflect a department-wide funding strategy and include all transportation projects. The Six-Year Programs are implementation and funding documents, setting priorities for highway construction based on frequently changing political and fiscal conditions. As such, these programs are considered to be planning tools for capital (fiscal) 
outlays for transportation projects, and therefore do not reflect accurately what actually got built or when projects were started. Another shortcoming of the programs is that multi-year projects may be represented a number of times, with changing costs, descriptions, lengths and durations. Repetition and touble-counting" of projects was therefore unavoidable. In this study, only highway projects were used for analysis and comparison purposes.

\section{Description of the Six-Year Program}

The Six-Year Program is published biennially (except the first two published one year apart), and lists highway projects for the next six fiscal years. The Programs reflect changes primarily for the two earliest years in each Program, thus having two new years added to each program at the end, for example: $1980-85,1982-87,1984-89$, etc. This twoyear revision cycle for a six-year planning document leads to a carryover effect and leads to the "double-counting"problem described above. The Programs followed a state fiscal year (July 1 to June 30) until the 1987-1992 Six-Year Program, which adopted the federal fiscal year (October 1-September 30). Organization of the Programs vary slightly, but generally follow a pattern of four types of projects: construction, development, reconnaissance, and considered. Projects in the first three categories have identified funding, while considered projects comprise a "wish list" of unfunded projects requested by local jurisdictions or the state. Projects are then broken down by highway region, and then divided by fiscal year. Only projects listed in the construction section have funds programmed for construction; the categories of development and reconnaissance consist of projects in the design or preliminary planning stages. Highway projects used in this study were taken from the construction category only; thus keeping the focus on programmed projects and a reasonable number of entries for the evaluation and analysis dataset. 
The Oregon Department of Transportation uses five geographic regions for administrative purposes. Projects in the Six-Year Programs are also divided by region. Region 1 is primarily composed of the greater Portland metropolitan area and a small rural area surrounding it. Region 2 covers the entire north Pacific Ocean coast of the state, and the mid Willamette Valley to the crest of the Cascade Mountains. Region 3 covers the southwestem part of the state from the Pacific coast of Oregon to the crest of the Cascades. Region 4 is the entire central portion of the state, while Region 5 is the entire eastern portion of the state. Figure 1 shows the state, county and regional boundaries for the state of Oregon.

Construction projects are identified by a map index number within each region, and keyed (with a project identifier number) to a location on an accompanying region vicinity map. Each project lists the signed route number, ODOT highway name, county, work section and length in miles, work description, estimated construction cost, and projected year and type of project funding. Some variations occur in this format from Program to Program, but all contain the same basic information. One important consideration is that, given the format of the Programs, each project in each Program has its own unique identifier; these identifiers do not carry over from Program to Program and thus make it difficult to avoid or minimize "double-counting"of projects.

One important fact concerning these construction projects is that they are planned; for any given Six-Year Plan, many projects were not built. This is especially true for later projects in each Plan, and some projects can be found as "carry-over" projects in later Programs. A good example is the 1993-98 Plan; this plan was renamed as the State 


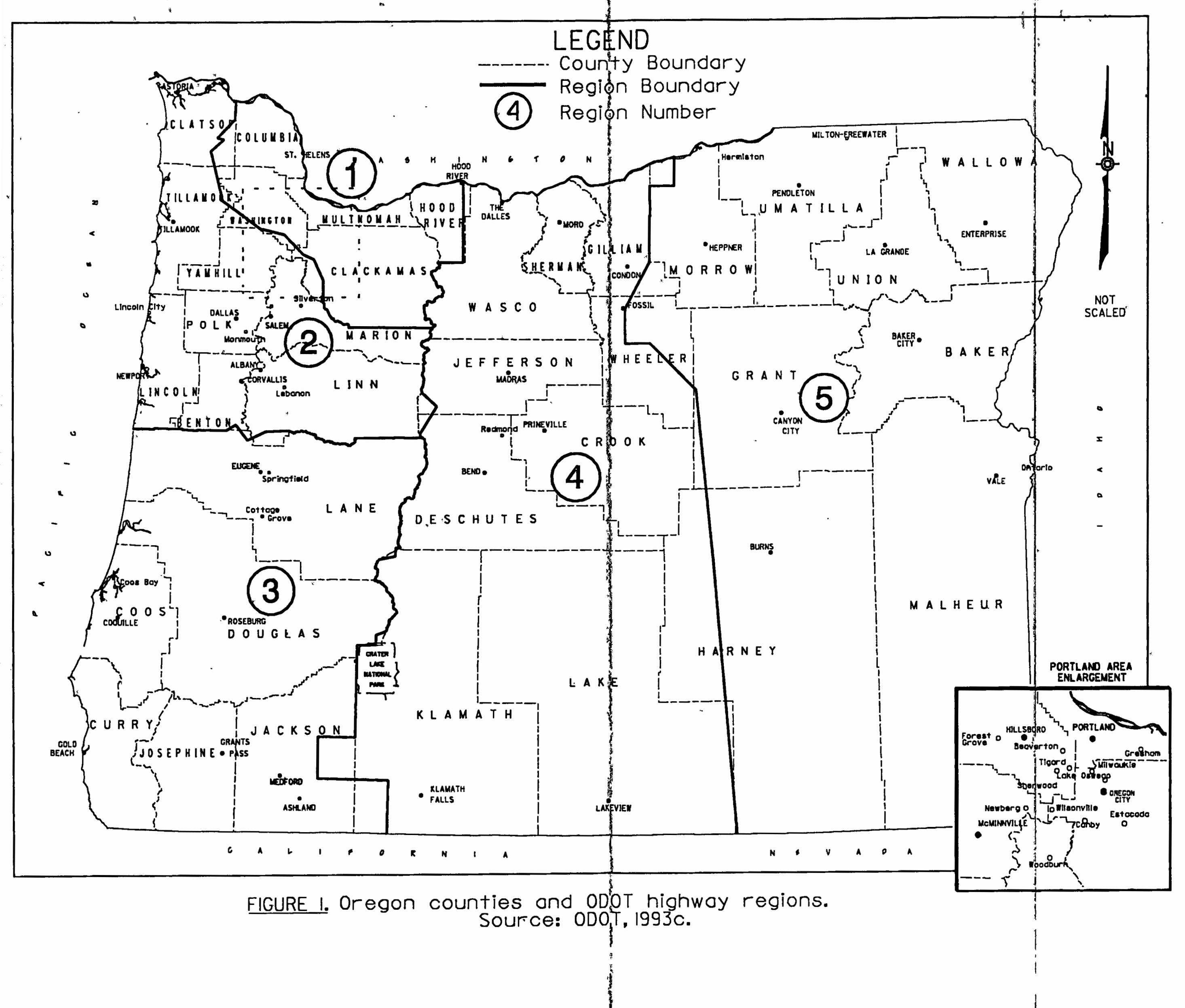


Transportation Improvement Program (STIP), to better reflect the inclusion of all state transportation projects, not just highway projects. The 1993-98 STIP was a very ambitious program, based upon assumptions of full federal funding and increased state funding through state legislative measures. In fact neither the federal or state anticipated funding increases came to pass, and the 1993-98 STIP was greatly over-programmed (ODOT, 1992c). This STIP has been revised for the next iteration, and has been scaled back to a four-year STIP: the 1995-98 STIP (ODOT, 1994). This new Program, issued in December, 1994, has the last four years of the previous plan (but no new program years added), but even fewer projects. New federal funding policies and regulations stipulate state programs to be 'fiscally constrained' to reflect realistic proposed expenditures based upon projected existing revenues. The latest STIP, to be published in Winter 1996, is the preliminary 199698 interim STIP", this will be used in light of further funding cuts and a revised publication schedule.

\section{County Area, Population, Vehicle Miles Traveled (VMT), and Income Data}

Land areas for Oregon counties were obtained from the 1993 edition of the Oregon Blue Book, published biennially by the Oregon Secretary of State. The areas for the counties, in square miles, (Oregon Secretary of State, 1993) are listed in Table I; this table also lists total state highway mileage for each county (ODOT, 1991c).

Population data was assembled from the Center for Population Research and Census (the Center) at Portland State University in Portland, Oregon. The Center has been designated by the State as the official entity charged with tabulating State population data and estimating census data in between federal decennial censuses. Population data obtained from the Center was entered into a spreadsheet and tabulated. The population 
TABLE I

OREGON HIGHWAY MILEAGE BY COUNTY AND LEVEL OF IMPORTANCE WITH LAND AREA (SQ. MI.) BY COUNTY

\begin{tabular}{|c|c|c|c|c|c|c|c|}
\hline COUNTY & $\#$ & $\begin{array}{l}\text { Interstate } \\
\text { Highways } \\
\end{array}$ & $\begin{array}{l}\text { Statewide } \\
\text { Highways } \\
\end{array}$ & $\begin{array}{l}\text { Regional } \\
\text { Highways } \\
\end{array}$ & $\begin{array}{c}\text { District } \\
\text { Highways } \\
\end{array}$ & $\begin{array}{c}\text { TOTAL } \\
\text { Highways } \\
\end{array}$ & $\begin{array}{l}\text { LAND AREA } \\
\text { (Sq. Mi.) } \\
\end{array}$ \\
\hline Baker & 1 & 65.80 & 22.67 & 43.38 & 169.16 & 302.01 & 3089 \\
\hline Benton & 2 & 0.00 & 19.36 & 42.40 & 57.32 & 121.08 & 679 \\
\hline Clackamas & 3 & 20.84 & 94.21 & 12.94 & 125.98 & 256.97 & 1879 \\
\hline Clatsop & 4 & 0.00 & 88.69 & 0.00 & 77.81 & 170.50 & 873 \\
\hline Columbia & 5 & 0.00 & 51.19 & 0.00 & 41.88 & 98.07 & 687 \\
\hline Coos & 6 & 0.00 & 96.16 & 0.00 & 72.55 & 174.71 & 1629 \\
\hline Crook & 7 & 0.00 & 46.19 & 9.98 & 117.65 & 180.82 & 2991 \\
\hline Curry & 8 & 0.00 & 77.10 & 0.00 & 5.55 & 90.65 & 1648 \\
\hline Deschutes & 9 & 0.00 & 177.04 & 2.31 & 44.67 & 233.02 & 3055 \\
\hline Douglas & 10 & 87.75 & 109.36 & 87.39 & 53.61 & 348.11 & 5071 \\
\hline Gilliam & 11 & 34.95 & 0.00 & 41.13 & 58.12 & 145.20 & 1223 \\
\hline Grant & 12 & 0.00 & 172.09 & 26.82 & 34.88 & 245.79 & 4528 \\
\hline Harney & 13 & 0.00 & 123.69 & 93.68 & 75.91 & 306.28 & 10228 \\
\hline Hood River & 14 & 25.64 & 38.62 & 0.00 & 25.32 & 103.58 & 533 \\
\hline Jackson & 15 & 52.19 & 38.45 & 0.00 & 186.40 & 292.04 & 2801 \\
\hline Jefferson & 16 & 0.00 & 66.71 & 16.30 & 12.33 & 111.34 & 1791 \\
\hline Josephine & 17 & 28.07 & 45.50 & 1.66 & 60.74 & 152.97 & 1641 \\
\hline Klamath & 18 & 0.00 & 211,93 & 94.67 & 78.24 & 402.84 & 6135 \\
\hline Lake & 19 & 0.00 & 14.54 & 229.28 & 62.68 & 325.50 & 8359 \\
\hline Lane & 20 & 39.50 & 207.54 & 40.88 & 148.36 & 456.28 & 4620 \\
\hline Lincoln & 21 & 0.00 & 101.49 & 0.00 & 71.90 & 194.39 & 992 \\
\hline Linn & 22 & 37.11 & 52.93 & 80.15 & 77.48 & 269.67 & 2297 \\
\hline Malheur & 23 & 26.01 & 258.94 & 39.31 & 75.84 & 423.10 & 9926 \\
\hline Marion & 24 & 40.14 & 59.61 & 22.73 & 84.91 & 231.39 & 1194 \\
\hline Morrow & 25 & 27.86 & 0.00 & 75.51 & 73.31 & 201.68 & 2049 \\
\hline Multnomah & 26 & 68.95 & 27.10 & 0.00 & 99.83 & 221.88 & 465 \\
\hline Polk & 27 & 0.00 & 40.76 & 35.78 & 44.86 & 148.40 & 745 \\
\hline Sherman & 28 & 14.70 & 48.54 & 16.92 & 35.58 & 143.74 & 831 \\
\hline Tillamook & 29 & 0.00 & 76.97 & 32.51 & 37.01 & 175.49 & 1125 \\
\hline Umatilla & 30 & 77.84 & 96.89 & 71.91 & 142.00 & 418.64 & 3231 \\
\hline Union & 31 & 42.21 & 31.95 & 19.65 & 101.55 & 226.36 & 2038 \\
\hline Wallowa & 32 & 0.00 & 44.90 & 0.00 & 72.57 & 149.47 & 3153 \\
\hline Wasco & 33 & 32.13 & 26.94 & 60.74 & 92.83 & 245.64 & 2396 \\
\hline Washington & 34 & 8.82 & 54.75 & 36.25 & 73.11 & 206.93 & 727 \\
\hline Wheeler & 35 & 0.00 & 45.86 & 66.39 & 43.18 & 190.43 & 1713 \\
\hline Yamhill & 36 & 0.00 & 32.80 & 45.06 & 70.32 & 184.18 & 718 \\
\hline Statewide & TOTALS & 730.51 & $2,701.47$ & $1,345.73$ & $2,705.44$ & $7,483.15$ & 97060 \\
\hline
\end{tabular}

Sources: $\quad$ ODOT, 1991c (Highway Mileages).

Oregon, Secretary of State, 1993 (County Areas). 
data was tabulated by county, with urban and rural breakdowns and a county total. Each of the five Program years was thus tabulated, with statewide totals for each year; this data was used in the datasets. Population data is shown in Table II, which tabulates total county population for each program year and percentage increases per year and for the total time span from 1978 to 1992.

Vehicle Miles Traveled (VMT) data was obtained from the Oregon Department of Transportation's Transportation Data Section. This data is collected each year for all local roads and state highways by county, and is a summation of road miles driven by all vehicle types on roadways within the state. Data for the selected plan years for this project was requested, and then tabulated into the countywide dataset. This data is shown in Table III, and is for state highways only in each county.

The Oregon Department of Human Resources, Employment Division, Research and Statistics branch compiles annual statistics on per capita personal income in the state. The Research and Statistics branch publishes a summary sheet of this data covering the last two decades. The most recent data published, and used for this study, is for 1992 . Per capita income data for the year of preparation of each of the five study Six-Year Programs was tabulated by county and as a statewide average.

\section{ODOT's Level-of-Importance (LOI) Highway Classification System}

The Oregon Department of Transportation developed the LOI highway classification system in 1985 as part of the first Oregon Highway Plan. In the 1985 Oregon Highway Plan, the system had three levels: interstate, statewide and regional, ranking from most to least important. Interstate highways are high volume facilities connecting not only with other states, but also serving Oregon's largest population centers. Highways in the 
TABLE \|

OREGON POPULATION BY COUNTY

\begin{tabular}{|c|c|c|c|c|c|c|c|c|}
\hline COUNTY & $\#$ & 1978 & 1982 & 1986 & 1988 & 1992 & $\begin{array}{c}\% \text { Increase } \\
\text { Total }\end{array}$ & $\begin{array}{c}\% \text { Increase } \\
\text { per year }\end{array}$ \\
\hline Baker & 1 & 16,050 & 16,240 & 15,500 & 15,100 & 15,800 & -1.56 & -0.11 \\
\hline Benton & 2 & 66,900 & 69,600 & 68,100 & 70,100 & 72,900 & 8.97 & 0.64 \\
\hline Clackamas & 3 & 233,100 & 245,100 & 248,200 & 262,200 & 294,500 & 26.34 & 1.88 \\
\hline Clatsop & 4 & 31,400 & 32,700 & 32,900 & 34,000 & 33,100 & 5.41 & 0.39 \\
\hline Columbia & 5 & 33,900 & 36,200 & 36,100 & 36,800 & 38,800 & 14.45 & 1.03 \\
\hline Coos & 6 & 62,950 & 61,750 & 57,500 & 58,800 & 62,100 & -1.35 & -0.10 \\
\hline Crook & 7 & 12,350 & 12,900 & 13,500 & 13,300 & 15,000 & 21.46 & 1.53 \\
\hline Curry & 8 & 15,900 & 17,200 & 16,900 & 18,400 & 21,400 & 34.59 & 2.47 \\
\hline Deschutes & 9 & 53,950 & 64,350 & 65,400 & 68,700 & 82,600 & 53.10 & 3.79 \\
\hline Douglas & 10 & 90,250 & 92,050 & 92,700 & 93,000 & 96,300 & 6.70 & 0.48 \\
\hline Gilliam & 11 & 2,150 & 1,960 & 1,800 & 1,850 & 1,750 & -18.60 & -1.33 \\
\hline Grant & 12 & 7,875 & 7,970 & 8,350 & 8,350 & 8,000 & 1.59 & 0.11 \\
\hline Harney & 13 & 7,775 & 7,515 & 7,100 & 7,400 & 6,950 & \begin{tabular}{|c|}
-10.61 \\
\end{tabular} & -0.76 \\
\hline Hood River & 14 & 15,800 & 15,870 & 16,200 & 16,500 & 17,600 & 11.39 & 0.81 \\
\hline Jackson & 15 & 126,900 & 133,725 & 138,400 & 143,400 & 152,900 & 20.49 & 1.46 \\
\hline Jefferson & 16 & 11,150 & 12,225 & 12,000 & 11,900 & 14,600 & 30.94 & 2.21 \\
\hline Josephine & 17 & 56,250 & 59,000 & 61,450 & 64,000 & 65,400 & 16.27 & 1.16 \\
\hline Klamath & 18 & 58,200 & 59,200 & 56,700 & 57,300 & 59,400 & 2.06 & 0.15 \\
\hline Lake & 19 & 6,975 & 7,625 & 7,300 & 7,300 & 7,350 & 5.38 & 0.38 \\
\hline Lane & 20 & 262,700 & 270,650 & 261,650 & 273,700 & 293,700 & 11.80 & 0.84 \\
\hline Lincoln & 21 & 32,200 & 36,600 & 36,900 & 38,800 & 39,600 & 22.98 & 1.64 \\
\hline Linn & 22 & 86,450 & 88,850 & 86,050 & 88,800 & 95,000 & 9.89 & 0.71 \\
\hline Malheur & 23 & 26,000 & 27,175 & 26,200 & 26,400 & 26,800 & 3.08 & 0.22 \\
\hline Marion & 24 & 191,700 & 207,350 & 209,200 & 219,000 & 241,500 & 25.98 & 1.86 \\
\hline Morrow & 25 & 6,675 & 7,260 & 7,800 & 7,800 & 8,100 & 21.35 & 1.52 \\
\hline Multnomah & 26 & 558,500 & 564,500 & 566,200 & 570,500 & 605,000 & 8.33 & 0.59 \\
\hline Polk & 27 & 44,300 & 45,060 & 45,600 & 47,300 & 53,000 & 19.64 & 1.40 \\
\hline Sherman & 28 & 2,000 & 2,210 & 2,100 & 2,000 & 1,800 & -10.00 & -0.71 \\
\hline Tillamook & 29 & 20,000 & 21,150 & 21,300 & 21,400 & 22,500 & 12.50 & 0.89 \\
\hline Umatilla & 30 & 55,100 & 60,000 & 58,700 & 57,600 & 61,100 & 10.89 & 0.78 \\
\hline Union & 31 & 23,350 & 24,410 & 23,000 & 23,300 & 24,000 & 2.78 & 0.20 \\
\hline Wallowa & 32 & 7,000 & 7,390 & 7,200 & 7,200 & 7,150 & 2.14 & 0.15 \\
\hline Wasco & 33 & 20,800 & 22,700 & 21,600 & 20,600 & 22,600 & 8.65 & 0.62 \\
\hline Washington & 34 & 221,450 & 259,700 & 273,300 & 287,000 & 340,000 & 53.53 & 3.82 \\
\hline Wheeler & 35 & 2,000 & 1,425 & 1,500 & 1,350 & 1,500 & -25.00 & -1.79 \\
\hline Yamhill & 36 & 51,750 & 56,575 & 57,100 & 59,800 & 69,200 & 33.72 & 2.41 \\
\hline Statewide & TOTAL & $2,521,800$ & $2,656,185$ & $2,661,500$ & $2,740,950$ & $2,979,000$ & 18.13 & 1.29 \\
\hline
\end{tabular}

Source: $\quad$ Portland State University, 1993, 1992 and 1989. 
TABLE III

OREGON VEHICLE MILES TRAVELED BY COUNTY

\begin{tabular}{|c|c|c|c|c|c|c|c|c|}
\hline COUNTY & $\#$ & 1978 & 1982 & 1986 & 1988 & 1992 & $\begin{array}{c}\% \text { Increase } \\
\text { Total }\end{array}$ & $\begin{array}{c}\% \text { Increase } \\
\text { per year }\end{array}$ \\
\hline Baker & 1 & 159,534 & 150,333 & 157,143 & 178,124 & 227,321 & 42.49 & 3.04 \\
\hline Benton & 2 & 164,377 & 160,982 & 175,490 & 199,186 & 222,389 & 35.29 & 2.52 \\
\hline Clackamas & 3 & 782,108 & 826,377 & $1,089,380$ & $1,222,920$ & $1,410,584$ & 80.36 & 5.74 \\
\hline Clatsop & 4 & 194,124 & 193,022 & 225,233 & 217,454 & 269,382 & 38.77 & 2.77 \\
\hline Columbia & 5 & 135,641 & 144,689 & 172,265 & 203,946 & 199,007 & 46.72 & 3.34 \\
\hline Coos & 6 & 305,316 & 289,796 & 303,962 & 328,225 & 375,186 & 22.88 & 1.63 \\
\hline Crook & 7 & 52,715 & 54,032 & 62,380 & 60,459 & 85,780 & 62.72 & 4.48 \\
\hline Curry & 8 & 112,985 & 109,852 & 119.039 & 132,127 & 140,289 & 24.17 & 1.73 \\
\hline Deschutes & 9) & 281,626 & 291,248 & 347,207 & 379,110 & 488,569 & 73.48 & 5.25 \\
\hline Douglas & 10 & 784,199 & 701,227 & 864,374 & 920,782 & 990,350 & 26.29 & 1.88 \\
\hline Gilliam & 11 & 91,153 & 87,303 & 93,719 & 101,387 & 130,912 & 43.62 & 3.12 \\
\hline Grant & 12. & 61,966 & 58,135 & 61,403 & 63,085 & 68,475 & 10.50 & 0.75 \\
\hline Harney & 13 & 72,286 & 69,356 & 62,306 & 75,612 & 83,380 & 15.35 & 1.10 \\
\hline Hood River & 14 & 160,063 & 149,496 & 165,019 & 184,836 & 228,879 & 42.99 & 3.07 \\
\hline Jackson & 15 & 605,150 & 586,534 & 704,572 & 768,151 & 834,332 & 37.87 & 2.71 \\
\hline Jefferson & 16 & 107,377 & 108,612 & 116,618 & 126,774 & 147,740 & 37.59 & 2.68 \\
\hline Josephine & 17 & 306,026 & 302,210 & 363,882 & 392,010 & 419,092 & 36.95 & 2.64 \\
\hline Klamath & 18 & 393,922 & 350,685 & 370,570 & 418,422 & 456,110 & 15.79 & 1.13 \\
\hline Lake & 19 & 61,566 & 56,758 & 58,934 & 64,020 & 79,081 & 28.45 & 2.03 \\
\hline Lane & 20 & $1,028,907$ & 999,713 & $1,092,065$ & $1,206,852$ & $1,308,984$ & 27.22 & 1.94 \\
\hline Lincoln & 21 & 226,816 & 238,976 & 279,634 & 315,271 & 327,941 & 44.58 & 3.18 \\
\hline $\operatorname{Lin} n$ & 22 & 600,197 & 585,412 & 678,083 & 765,519 & 852,050 & 41.96 & 3.00 \\
\hline Malheur & 23 . & 206,221 & 201,339 & 205,264 & 229,622 & 274,466 & 33.09 & 2.36 \\
\hline Marion & 24 & 805,650 & 819,307 & 986,529 & $1,086,923$ & $1,220,420$ & 51.48 & 3.68 \\
\hline Morrow & 25 & 94,456 & 91,352 & 107,850 & 113,884 & 131,692 & 39.42 & 2.82 \\
\hline Multnomah & 26 & $1,724,199$ & $1,732,274$ & $2,219,583$ & $2,467,458$ & $2,725,186$ & 58.06 & 4.15 \\
\hline Polk & 27) & 216,177 & 212,621 & 245,852 & 280,388 & 318,276 & 47.23 & 3.37 \\
\hline Sherman & 28 & 65,625 & 66,919 & 76,176 & 78,998 & 95,044 & 44.83 & 3.20 \\
\hline Tillamook & 29 & 158,924 & 161,077 & 166,389 & 192,635 & 215,899 & 35.85 & 2.56 \\
\hline Umatilla & 30 & 371,612 & 357,288 & 384,384 & 408,587 & 493,251 & 32.73 & 2.34 \\
\hline Union & 31 & 146,473 & 135,613 & 157,859 & 168,188 & 217,382 & 48.41 & 3.46 \\
\hline Wallowa & 32 & 34,937 & 31,112 & 34,483 & 37.505 & 46,371 & 32.73 & 2.34 \\
\hline Wasco & 33 & 205,738 & 205,578 & 219,805 & 246,586 & 278,641 & 35.43 & 2.53 \\
\hline Washington & 34 & 870,138 & 966,329 & $1,204,854$ & $1,371,410$ & $1,458,210$ & 67.58 & 4.83 \\
\hline Wheeler & 35 & 16,256 & 18,504 & 18,694 & 18,740 & 20,849 & 28.25 & 202 \\
\hline Yamhill & 36 & 214,586 & 221,772 & 262,266 & 282,653 & 321,865 & 49.99 & 3.57 \\
\hline Statewide & TOTAL & $11,819,046$ & $11,735,833$ & $13,853,266$ & $15,307,849$ & $17,163,385$ & 45.22 & 3.23 \\
\hline
\end{tabular}

Source: $\quad$ ODOT, 1993b.

NOTE: $\quad$ All the above VMT data are in thousands (1000s) of miles. 
interstate category include only the signed interstate freeways $(1-5,1-82,1-84,1-105,1-205$, and 1-405). Statewide highways, such as US20, US26, US97, OR58, and OR42, are those which serve other population or economic centers within Oregon not served by the interstates. The statewide highways also serve as interstate connections. Regional highways, mostly Oregon state routes and some minor US routes, serve more of an intrastate local function. The regional routes connect smaller Oregon communities, or provide access to regional economic or recreational areas (ODOT, 1985).

The 1991 Oregon Highway Plan added another LOI to the three previous, this being the district Level-of-Importance. The district LOI was split apart from the previous regional classification to distinguish those highways serving an almost exclusively local function. The net result of this division was a large total of district highways and a rather small mileage total of regional highways. The significant aspect of this was a four tiered LOI system, with the order from most to least importance being: interstate, statewide, regional, and district. Another change in the 1991 Oregon Highway Plan versus the 1985 Oregon Highway Plan was a subdivision of the statewide category; this category is the Access Oregon Highway $(\mathrm{AOH})$ system. The $\mathrm{AOH}$ system was designated in 1986 to receive a half billion dollars in state funds over a ten year period to improve connectivity amongst economic/population centers outside the Willamette Valley. The $\mathrm{AOH}$ routes generally connect the Oregon coastal areas or central/eastem Oregon to other parts of the state via other statewide routes or interstate routes. For purposes of this report, however, all Access Oregon Highways are considered only as statewide facilities in the LOI classification (ODOT, 1991).

Highway mileages for the various LOl's were obtained from ODOT's Transportation Development Branch, Transportation Inventory and Mapping section. Mileage data was in 
two formats-computer printouts from the Automated Milepoint Log (AML) and the 1991 annual edition of the Oregon Mileage Report. The two data sets were compared for consistency, and then tabulated by LOI for each Oregon county (ODOT, 1993a) and the statewide totals (ODOT, 1993b). The LOI data is included in Table I, and graphically depicted on Figure 2.

\section{Administrative Boundaries}

One of the most convenient and widely used administrative units for data compilation is the Oregon county. All data used in this report has been correlated on a county basis, and most was received in a county-based form. Oregon has thitty-six counties; data used in this report is related to counties by a number from 1 to 36 , assigned to the counties in alphabetical order. Many state agencies, particularly ODOT, use the numerical values to identify counties. (Number 37 is assigned for statewide information in some ODOT data.) All data tables in this document list the counties alphabetically and include the county number.

ODOT uses another administrative and functional unit for its internal activities, the region. The state is divided into five regions roughly as follows:

1.) the Portland Metropolitan area;

2.) the Willamette valley and north Oregon coast;

3.) southem Oregon and the south Oregon coast;

4.) central Oregon, and;

5.) eastem Oregon.

The region boundaries do not follow county boundaries in all instances, but closely enough for rough groupings. Figure 1 shows the relationship of Oregon counties to ODOT regions. 


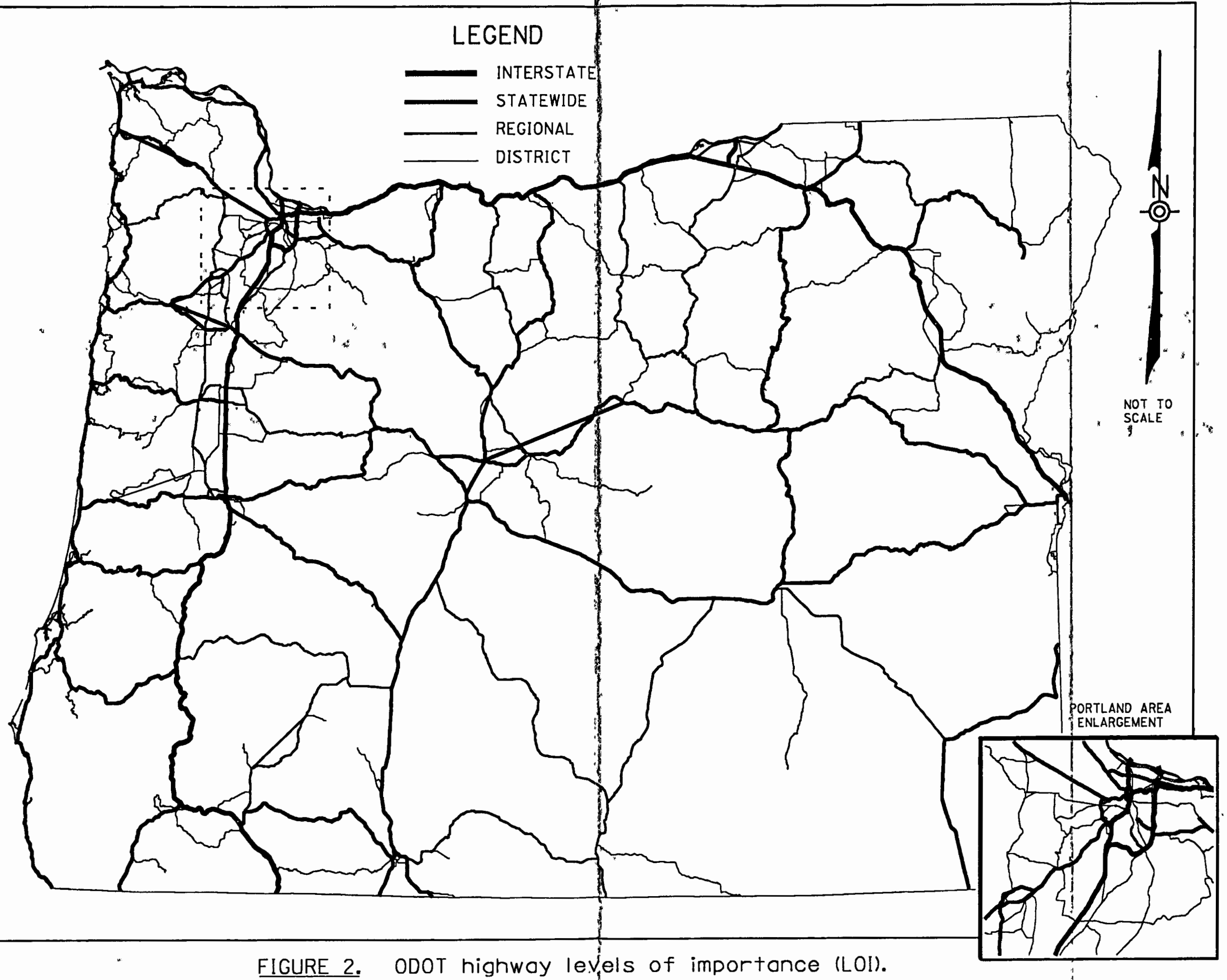

FIGURE 2. ODOT highwoy levels of importance (LOI). Source: ópot, 1993c. 
For data reported by region, it was assumed that if most of a county was within one region (as shown on Figure 1), it would be counted for only that one region.

Project land use designations were determined from project descriptions contained in the various Programs. In addition to the project name (in part a description), the Programs listed beginning and ending milepoints for each project. Each state highway has its own discrete set of milepoints for its entire length, and by comparing milepoints with jurisdictional boundaries (from ODOT computer files and maps), a generic land use of urban or rural was developed.

The highway milepoints were also used for the length of projects by determining the difference between beginning and ending milepoints. Later Programs deleted the milepoints for beginning and end, instead giving a total project length. 


\section{DATA BASE CREATION METHODOLOGY}

Some method of compilation had to be developed in order to perform any analysis between Six-Year Programs. The first consideration was which plans to include; the first two Programs (the 1976-81(OSHD, 1975) and 1976-82 (OSHD, 1976) were dropped because they were only a year apart. The first Program included is the 1979-1984 Program (ODOT, 1978). The 1980-85 Program (ODOT, 1980) was not included since it was only one year after the 1979-84 Program. The 1982-1987 Program (ODOT, 1982) was included because it was developed during an economic recession, representing a 'minimum expenditure', or fiscally constrained program. The 1984-89 Program (ODOT, 1984) was not included. The 1987-1992 Program (ODOT, 1986) was included to represent the most "typical" financial and organizational period for ODOT. The 1989-1994 Program (ODOT, 1988) was included due to a large injection of state funding (from the Access Oregon Highways program). The 1991-96 Program (ODOT, 1990) was not included since it was almost a duplication of the previous Program. Finally, the 1993-1998 Program was selected to reflect ODOT reorganization and a new federal funding program in the form of the Intermodal Surface Transportation Efficiency Act (ISTEA). The five included Programs were each prepared after a major funding change or a departmental reorganization/policy shift, and would be most likely to reflect those changes in construction project funding statewide. The last two Programs, the 1995-98 and the 1996-98, were (or will be) published after work was begun on this project, and therefore were not considered; these last two Programs also were not six-year programs. 
ODOT's Program Section, the unit responsible for preparation and publication of the Six-Year Programs, did not have any of the Programs on computer files, therefore a database file had to be created. This file is composed of the numbered construction projects from the five Programs 1979-1984, 1982-1987, 1987-1992, 1989-1994, and 19931998; these will be referred to as the $1978,1982,1986,1988$, and 1992 Programs. It must be emphasized that only construction projects were included, since these were the only ones actually programmed to be built. Each construction project was identified by the map index number prefaced by a letter; the letter prefix ( $A$ through $E$ ) identified the Six-Year Program in chronological order from the earliest to latest.

The selected programs contained lots of data not germane to this project, and did not posses other data deemed to be necessary. Thus a new database needed to be constructed from the selected five programs, plus supplemental data from other previously described sources. The project database consists of ten attributes for each project; each attribute was condensed into as few characters as possible. The ten project attributes are:

- 1. project identification (as described above - a unique number designating which Program the project came from; the code is an initial letter followed by three digits, with the letters A through $\mathrm{E}$ corresponding to $1978,1982,1986$, 1988, and 1992);

- 2. region (ODOT highway region number, from 1 to 5 );

- 3. county (1 -36 alphabetically, with 37 used for statewide projects);

- 4. land use (urban or rural, as determined from project descriptions and highway milepoints as described in the five Programs);

- 5. highway designation (Interstate route, US route or Oregon route number);

- 6. highway classification (ODOT level-of-importance); 
- 7. length of project (in miles and tenths of miles);

- 8. fiscal year (proposed first year of construction);

- 9. project cost (estimated construction cost in 1000's of dollars);

- 10. project work type (five general categories-see below).

The ten attributes for each project were taken directly from the five selected plans and abbreviated for easy use and coding with computer programs (ODOT, 1978, $1982,1986,1988$, and 1992c).

The "class" attribute refers to the ODOT highway classification scheme which is similar to a functional classification. Functional classifications for roads most often are described for roads at a local (city or county) level; ODOT uses a statewide classification scheme called the level-of importance (LOI). The LOI system is a four level classification scheme composed of Interstate (I), Statewide (S), Regional (R), and District (D) highways. Each state highway is assigned to one of the four levels depending on the areas it serves or links together. All projects in the database were assigned a LOI class from this system. Highway LOl's were more fully described in a previous section.

The "work type" attribute describes one of five general construction categories: modernization $(\mathrm{M})$; preservation $(\mathrm{P})$; safety $(\mathrm{S})$; bridge $(\mathrm{B})$; and miscellaneous $(\mathrm{X})$. Modernization includes new construction, widening and major alignment corrections. Preservation is mostly limited to pavement overlays and minor repaving. Safety projects correct highway safety problems such as rockfall mitigation, channelization (such as adding left-turn lanes) and traffic signal installation. Bridge projects include replacement and structural repair of bridges. Miscellaneous work includes projects at rest areas, weigh stations, landscaping, etc. Projects from all five Programs were categorized using this work type classification, even though it was only adopted in the last Program. All Programs 
included a work description which was directly transferred to the "work type" attribute taken from the 1992 Six-Year Program. 


\section{INITIAL DATASET ANALYSIS METHODOLOGY}

\section{General Information}

Cost was selected as the evaluation variable. Any useful measure for determining geographic distribution of planned highway projects throughout the state could be evaluated against cost, since expenditure criteria are commonly used and readily understood. In most of the evaluations, costs in a given program year were calculated, this being used for comparisons over time. The independent variables used would have to posses quantifiable parameters such as population, which could be related to distinct areas, in this analysis by counties of the state. Ultimately the independent variables evaluated included population, area, total highway mileage, and vehicle miles traveled (VMT). Later analyses included derived variables such as population density or VMT per capita.

The initial dataset contained the original ten project attributes. This initial dataset was used to create the "county dataset. The county dataset contained summarized and derived data from the initial dataset grouped by county, plus additional data available only as countywide data. The final dataset used for analysis, henceforth referred to as the project" dataset, consisted of the project dataset combined with selected county parameters. The county data could be attached to the initial data based upon county identification and program year.

The project database was first created in the dBase III program. Subsequently the project database was imported to Microsoft Windows Excel 5.0, where the initial data manipulations were performed. Excel was subsequently used with the project, county and combined datasets to perform simple grouping, sorting and calculation functions. More 
complex statistical analysis was later done with SPSS 6.0 for Windows. The SPSS analysis consisted primarily of multiple regression runs for both datasets.

\section{Aggregated County Data Analysis}

At the beginning of the analysis, rough cost comparisons were performed based upon highway regions. Problems became evident with this approach, which led to its elimination for further analyses. One problem was that of region geographic boundaries not following county boundaries, but being rather arbitrary; this was not acceptable. A second problem was that a sample size of five, versus thirty-six, gave rather coarse data not entirely suited for valid analysis. It should be pointed out, however, that the 4992 ODOT County Equity Study" evaluated some data based on highway regions (ODOT, 1992c). The next set of evaluations was performed using the Programs (a dataset of five: 1978, 1982 , 1986,1988 , and 1992) to determine if any trends were apparent.

The first database analysis consisted of simple breakdowns and summations of the project data into county-based totals of proposed costs by highway LOI, with total work types (such as safety and preservation) and mileages also included. Selected data was then tabulated and plotted as bar graphs for each Program, with proposed cost plotted against work type and highway LOI. Two graphs were prepared for each work type and LOI plot - one showing absolute dollar expenditures, and the other being a percentage of total expenditures graph. These graphs are included as Figures 3 through 6 , with Figures 3 and $\underline{4}$ describing work type and Figures 5 and 6 describing LOI expenditures. An apparent discrepancy should be noted concerning Figures 3 through 6 , and that is these Figures use the total program year range, rather than the program year of publication, to identify which 


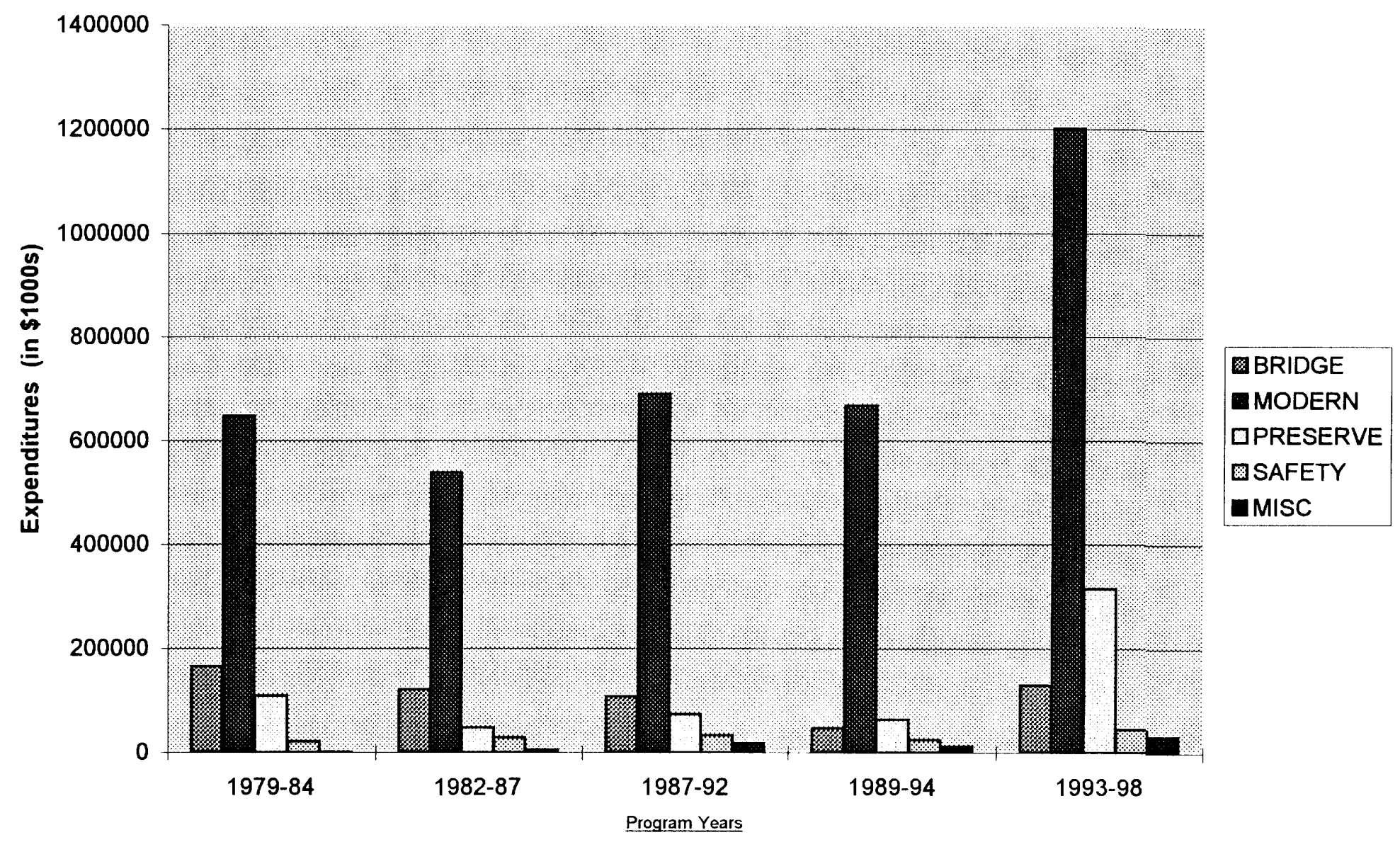

FIGURE 3. Planned ODOT expenditures by work type and program. 


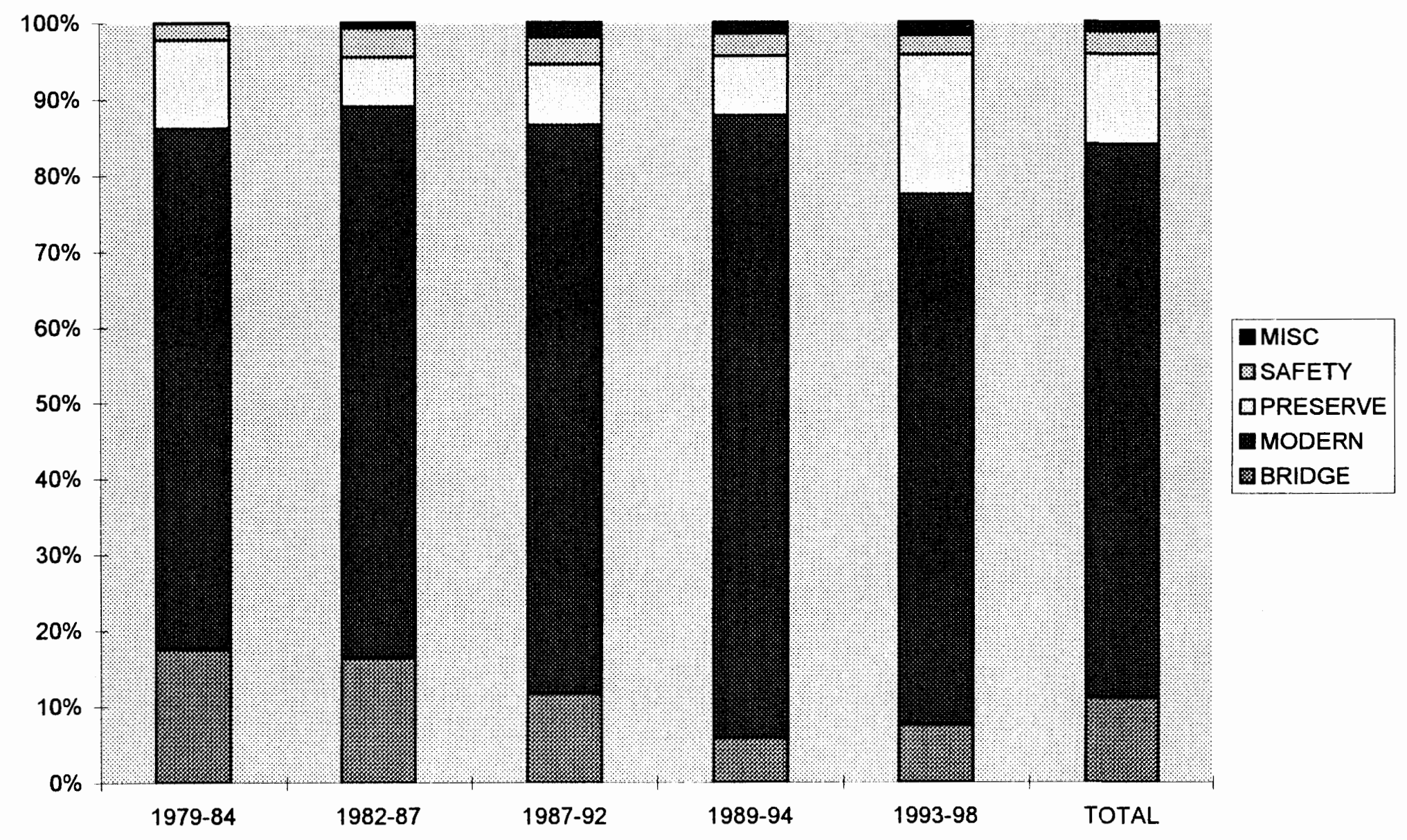




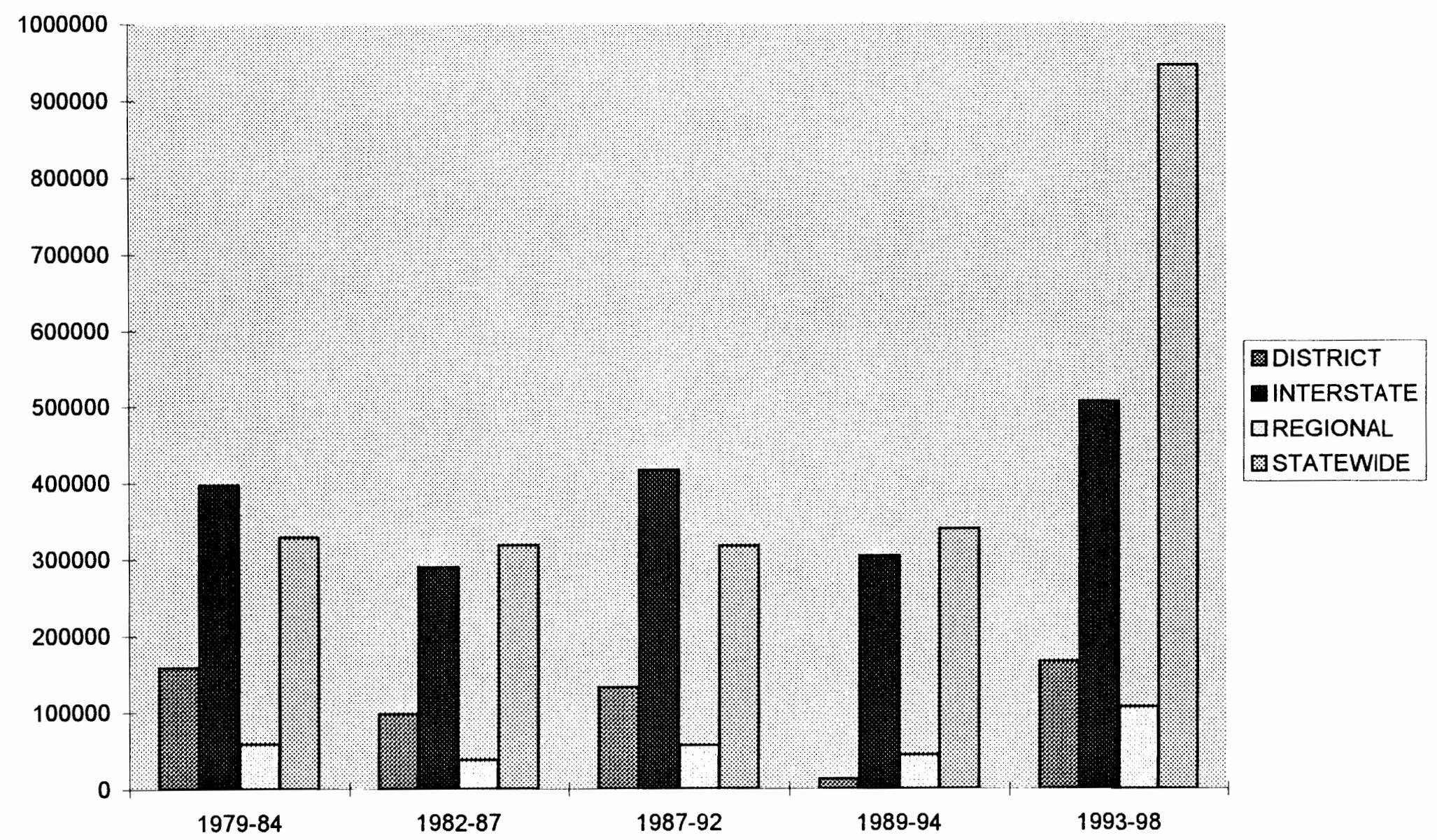

FIGURE 5. Planned ODOT expenditures by highway level of importance (LOI) and program. 


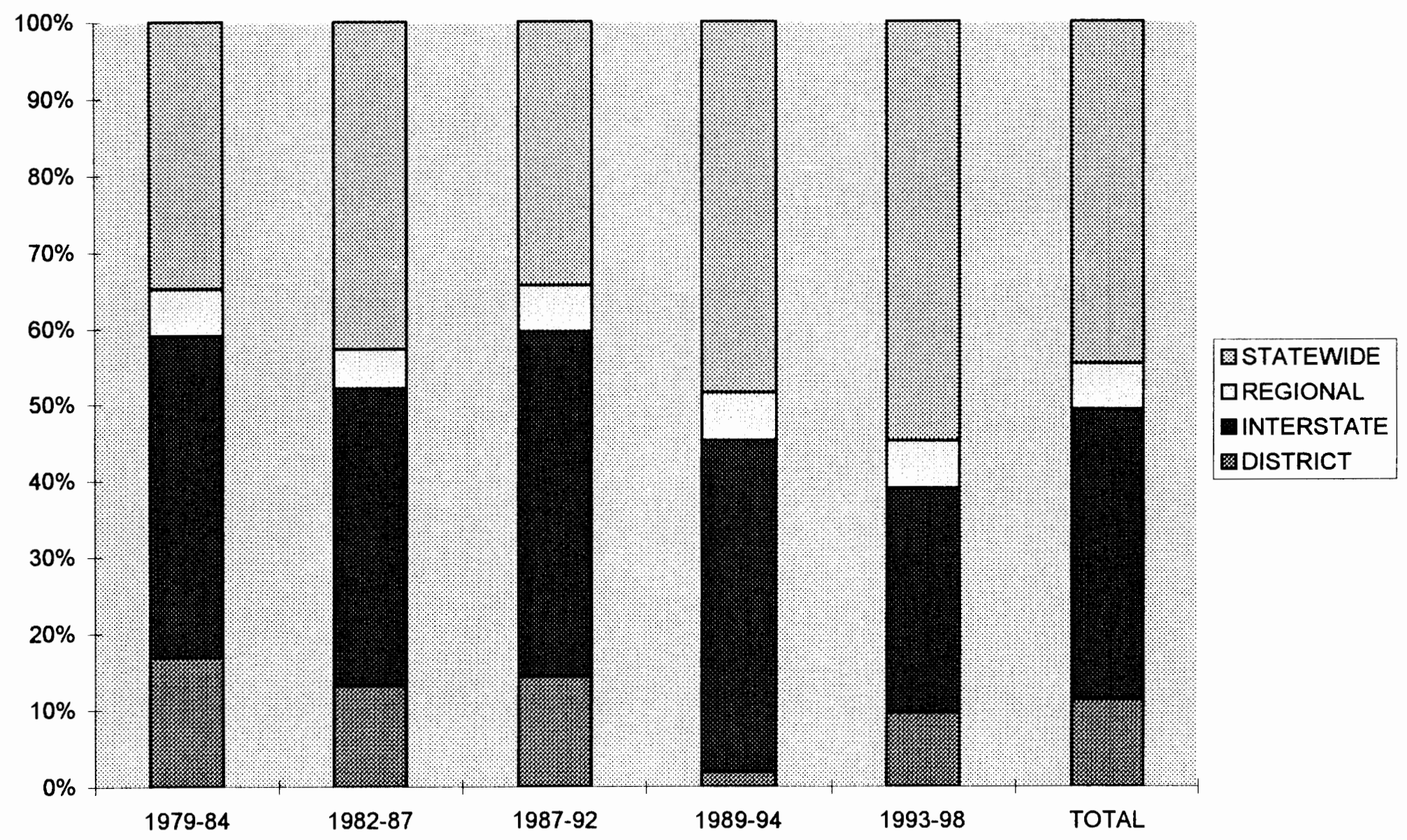


program is being evaluated. In the case of Figures 3 through 6 , merely subtract one year from the first year of the range listed to obtain the corresponding Program year as used throughout the remainder of this report.

Examination of Figures 4 and 6 , depicting planned expenditures as percentages of the total program, show some interesting trends. Figure 4 shows that modernization project expenditures grew from 1978 to 1988 , primarily at the expense of bridge and preservation projects. In 1992 the modemization projects have been decreased in favor of preservation, and to a lesser extent, bridge projects. The increase in preservation projects in the 1992 program may reflect the intent of the federal ISTEA program, which emphasized maintenance of existing roadways over the construction of new ones. The steady, but relatively slow growth of both safety and miscellaneous projects can be attributed to better project type definition over the duration of the project programming process conducted by ODOT; for example, in earlier programs, the category of miscellaneous did not even exist (one more reason for excluding the first two Programs from the analysis). Figure 6 plots the percentages of proposed expenditures for the five study Programs in terms of highway level of importance (LOI). Planned expenditures on interstate highways remained fairly constant from 1978 to 1988 , but decreased quite significantly in 1992 in order fund more work on statewide highways (a trend which began in the 1986 program). This increase of expenditures for statewide highways versus interstate highways, beginning in 1986, can be attributed to the state of Oregon's enactment of a gas tax for the Access Oregon Highways program in 1986; all of the AOH highways are statewide LOI facilities (ODOT, 1986).

Figures 3 through 6 show general trends of relatively steady investments for both modernization work and interstate highways from 1978 to 1988 . An increase in preservation work and work on statewide highways in the 1992 program, reflect the 
changes of both state and federal priorities due to the state's $\mathrm{AOH}$ program and the federal ISTEA program. This coarse analysis helped to focus on the need to develop more meaningful data regarding project work type, and the highway level of importance.

Further data measures were developed by incorporating county-based raw data, such as population and VMT, with the project-by-county data summaries. Examples of this type of derived data include cost per mile per highway LOI, VMT per capita, cost per mile per square mile, and population density. Additionally, the four highway LOI categories were put into two new groups: the first being primary highways, composed of the interstate and statewide LOls; the second being secondary highways, composed of the regional and district LOls. The Oregon highway system is often categorized on the primary/secondary basis, and until 1985 was the only categorization scheme used by ODOT; use of this twotiered highway classification system simplified analysis without loss of detail. This expanded county dataset now included ten original variables, a half dozen county variables plus over a dozen of the newly derived variables. This expanded county dataset was the basis for all remaining analysis of gross county data. Printouts of all five county datasets are included as Appendix A.

1988 was selected as the sample program year for the most complete analysis, which would indicate which variables might be significant and which might be eliminated from further consideration. The 1988 program was selected because it reflected a fullfunding program"at both state and federal levels, therefore having the greatest potential for showing equitable geographic project expenditure distributions.

A number of pairs of the derived data sets were plotted against each other on scatter diagrams; then a bivariate linear regression was performed and plotted on the charts. These simple bivariate linear regressions were performed in the Excel spreadsheet 
program. Initial plots and calculations used the county, by number, as the dependent variable, plotted against cost per unit $(x)$ as the independent variable. The cost variable was an aggregate cost of all five types of projects within each county for 1988. Simple bivariate linear regression results of these plots were not indicative of good correlation, with Rsquared values of less than 0.25 . The next set of simple regressions on the 1988 county program dataset differed in the use of a cost per unit $(x)$ per unit $(x)$; this was done in order to try and reduce the data scatter and get better correlation. A sample of the data used is shown in Table IV, while a sample plot is included as Figure 7. Figure 7 shows the plot of cost per mile (for total highways, primary plus secondary) per mile of highway type (in this case, total) per square mile plotted against the counties, arranged from smallest to largest land area. Similar regressions to those which were used to plot Figure 7 were done for each highway type, primary, secondary and total against population, population density, highway miles, VMT, and VMT per capita. This set of linear regressions produced slightly better results, but still not satisfactory: the highest $R$-squared value obtained was 0.3349 . The results of the fifteen bivariate linear regressions run for the 1988 sample dataset are shown in Table V.

Even though the results of the simple regression on the 1988 program sample county dataset were not conclusive, some observations were noted. The foremost observation was that further analysis should be done at the project level, since aggregated data results were inconclusive, based upon the low R-squared values shown above. A second observation was instead of simple linear regression, multiple regression should be used for analysis. The third observation concerned the data itself : which to eliminate in further analysis. Data withheld from future analysis included per capita income, any of the (cost per unit $(x)$ per unit $(x)$ ) variables, land use, or population breakdowns by urban or 
TABLE IV

1988 PROJECT COST PER MILE PER MILE PER SQUARE MILE BY COUNTY

\begin{tabular}{|c|c|c|c|c|c|}
\hline \multirow[b]{2}{*}{ COUNTY } & \multicolumn{4}{|c|}{ Cost / Mi / Mi of $\mathrm{Hwy} / \mathrm{Sqr} \mathrm{Mi}$} & \multirow{2}{*}{$\begin{array}{c}\text { AREA } \\
\text { (Sq. Mi.) }\end{array}$} \\
\hline & $\#$ & Primary & Seconday & TOTAL & \\
\hline$\overline{\text { Multnomah }}$ & 26 & 27.95 & 58.20 & 14.91 & 465 \\
\hline Hood River & 14 & 89.93 & 0.00 & 64.51 & 533 \\
\hline Benton & 2 & 659.29 & 35.83 & 60.47 & 679 \\
\hline Columbia & 5 & 21.96 & 0.23 & 4.45 & 687 \\
\hline Yamhill & 36 & 53.85 & 0.00 & 11.92 & 718 \\
\hline Washington & 34 & 42.28 & 8.25 & 11.02 & 727 \\
\hline Polk & 27 & 23.92 & 128.17 & 8.98 & 745 \\
\hline Sherman & 28 & 10.47 & 0.00 & 5.72 & 831 \\
\hline Clatsop & 4 - & 6.78 & 1796.02 & 11.65 & 873 \\
\hline Lincoln & 21 & 10.67 & 63.09 & 6.99 & 992 \\
\hline Tillamook & 29 & 12.01 & 4.88 & 5.62 & 1125 \\
\hline Marion & 24 & 7.34 & 4.43 & 2.96 & 1194 \\
\hline Gilliam & 11 [ & 0.55 & 2.03 & 0.19 & 1223 \\
\hline Coos & 6 & 13.04 & 106.11 & 15.74 & 1629 \\
\hline Josephine & 17] [ & 13.27 & 0.50 & 5.56 & 1641 \\
\hline Curry & 8 & 13.38 & 0.00 & 12.48 & 1648 \\
\hline Wheeler & 35 & 8.22 & 10.66 & 2.50 & 1713 \\
\hline Jefferson & 16 & 8.21 & 0.00 & 5.75 & 1791 \\
\hline Clackamas & 3 & 2.39 & 2.89 & 1.27 & 1879 \\
\hline Union & 31 & 1.40 & 0.45 & 0.52 & 2038 \\
\hline Morrow & 25 & 0.09 & 0.00 & 0.01 & 2049 \\
\hline Linn & 22 & 14.51 & 2.63 & 3.22 & 2297 \\
\hline Wasco & 33 & 6.29 & 0.16 & 1.03 & 2396 \\
\hline Jackson & 15 & 3.28 & 1.51 & 1.06 & 2801 \\
\hline Crook & 7 & 1.89 & 0.00 & 0.50 & 2991 \\
\hline Deschutes & 9 [ & 2.11 & 0.00 & 1.66 & 3055 \\
\hline Baker & 1 - & 4.44 & 3.96 & 1.31 & 3089 \\
\hline Wallowa & 32 & 0.55 & 1.54 & 0.72 & 3153 \\
\hline Umatilla & 30 & 1.33 & 0.69 & 0.49 & 3231 \\
\hline Grant & 12 & 0.48 & 0.00 & 0.35 & 4528 \\
\hline Lane & 20 & 0.70 & 0.51 & 0.35 & 4620 \\
\hline Douglas & 10 & 1.31 & 1.18 & 0.66 & 5071 \\
\hline Klamath & 18 & 0.48 & 0.09 & 0.11 & 6135 \\
\hline Lake & 19 & 0.00 & 0.24 & 0.23 & 8359 \\
\hline Malheur & 23 & 0.08 & 1.24 & 0.08 & 9926 \\
\hline Harney & 13 & 0.51 & 0.17 & 0.13 & 10228 \\
\hline
\end{tabular}

Source: Oregon Secretary of State, 1993 (Areas only).

NOTE: All costs in dollars and cents 


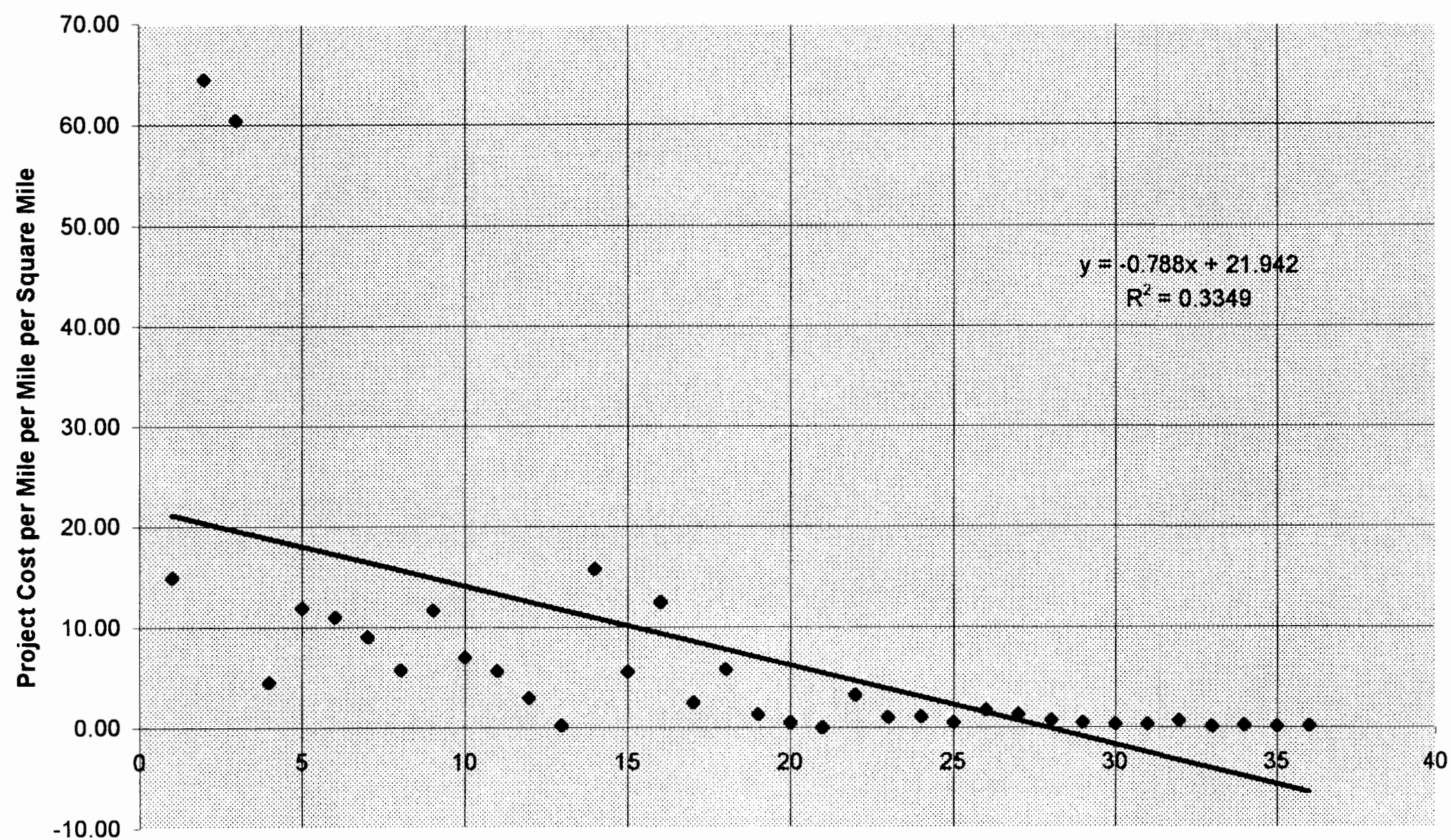

Counties, from Low to High Area

FIGURE 7. Cost per mile per mile of highway per square mile by county, total highways. 
rural. Land use designations were too arbitrary for useful analysis, and analysis of population data broken down in two components provided no insights.

\section{TABLE V}

County Dataset Linear Regression Results

\begin{tabular}{|c|c|c|c|}
\hline Dependent Variable & $\begin{array}{c}\text { Independent } \\
\text { Variable }\end{array}$ & Constant & R-Squared \\
\hline Cost/Mi/Capita, Primary & -0.0628 & +2.1191 & 0.1015 \\
\hline Cost/Mi/Capita, Secondary & -0.0708 & +3.2819 & 0.0089 \\
\hline Cost/Mi/Capita, Total & -0.0323 & +0.9836 & 0.2270 \\
\hline Cost/Mi/Sq Mi, Primary & -3.6981 & +97.997 & 0.1267 \\
\hline Cost/Mi/Sq Mi, Secondary & -5.4563 & +163.04 & 0.0370 \\
\hline Cost/Mi/Sq Mi, Total & -0.7880 & +21.942 & 0.3349 \\
\hline Cost/Mi/Unit Density, Primary & -121.44 & +3729.3 & 0.1622 \\
\hline Cost/Mi/Unit Density, Secondary & -77.923 & +3896.5 & 0.0117 \\
\hline Cost/Mi/Unit Density, Total & -55.141 & +1660.3 & 0.3148 \\
\hline Cost/Mi/Unit VMT, Primary & -0.0068 & +0.2566 & 0.0344 \\
\hline Cost/Mi/Unit VMT, Secondary & -0.0239 & +0.7134 & 0.0436 \\
\hline Cost/Mi/Unit VMT, Total & -0.0006 & +0.0514 & 0.0116 \\
\hline Cost/Mi/UnitVMT/Capita, Primary & -767.01 & +20277 & 0.0964 \\
\hline Cost/Mi/UnitVMT/Capita, Secondary & -280.83 & +14287 & 0.0052 \\
\hline Cost/Mi/UnitVMT/Capita, Total & -84.641 & +2801.4 & 0.1304 \\
\hline
\end{tabular}

NOTE: $P=$ Population $A=$ Area $\quad D=$ Population Density $V=V M T \quad C=V M T / C a p i t a$

The final observations regarding countywide linear regression were the effects of certain types of "abnormal" projects. These unusual projects were the bridge, safety and miscellaneous work type projects. Miscellaneous projects are unusual due to their limited numbers (a very low percentage of the total projects in any one program). Bridge projects are very short (usually one-tenth of a mile) but very expensive. Safety projects, on the other hand, are often quite long (up to over a hundred miles long for a sign replacement job) but very low cost. The net effect of the main two abnormal" types of projects, high cost/low mileage and low cost/high mileage, is to boost the cost per mile per mile variables, thereby skewing the data. Another effect of abnormal cost which can be inferred is that a large expenditure of money on one project, usually in one county (such as a bridge project), will 
tend to increase the cost per mile per mile to a higher degree than a low cost per mile per mile (typically a safety project) will lower the cost per mile per mile.

\section{Aggregate County Dataset Multiple Regression Analysis}

The next step was to perform multiple regression on selected variables in the county dataset to determine any significant relationships at the county level and to determine what to analyze in the project database. As with the simple linear regression, the 1988 program dataset was selected as the trial run, with total project costs per county as the dependent variable. This initial set of multiple regressions was run mainly to eliminate inconclusive variables for future multiple regressions at the project dataset level.

Three separate multiple regressions were run on the 1988 sample: 1.) cost versus total, primary and secondary highway LOI mileages; 2.) cost versus population, population growth rate and population squared; and 3.) cost versus population, area and population density. Examination of the regression results showed that the total highway mileage, population and population growth rates showed the most potential for further analysis, while density and area also indicated further promise. The variables which were dropped from further analysis included: the primary and secondary highway mileages, and population squared.

Further multiple regressions were run on the county datasets after the project datasets had been analyzed. These last multiple regression analyses were performed on the county datasets for all five program years, anc.' were warranted by examination of the project level regressions. Description and discussion of the results of the final county dataset regression analyses follows the description and analysis of the project datasets. 


\section{DETAILED PROJECT DATASET ANALYSIS}

\section{Project Dataset Composition}

The individual project dataset consisted of the original ten variables, plus the appended county data to each project. The appended data assumed that each project was unique to only one county. The appended data was based upon the plan year for the particular project, thus five datasets were formed from the all inclusive original; the hew" project datasets were now for $1978,1982,1986,1988$, and 1992. The inclusion of the countywide data in the project dataset enabled analysis at the project level, but capable of being examined using data available only at the aggregate county level. Another data type was used to supplement the project data set, this being dummy variables. Three categories of dummy variables were created for each project in all five datasets: work type, region and work type mileage. The first two were simply creating five new variables, with a 1 for the proper region or work type and a 0 in the other four variables. The third was similar, but used the project mileage combined with work type; this was coded as a one-place decimal number for the appropriate project work type, and a 0 for the other four categories. Ultimately the regional dummy variables were not used. The new appended data are listed as follows, along with a variable identifier, or name (shown in BOLD type). It should be noted the first ten variables are the variables used to create the original database.

- 1. project identification (a unique number also designating which Program the project came from), (ID);

- 2. region (ODOT highway region number, from 1 to 5), (RGN); 
- 3. county (1 -36 alphabetically, with 37 used for statewide projects), (CO);

- 4. land use (urban or rural, as determined from project descriptions and highway milepoints as described in the five Programs),(LU);

- 5. highway designation (Interstate route, US route or Oregon route number), (HWY);

- 6. highway classification (ODOT level-of-importance), (LOI);

- 7. length of project (in miles and tenths of miles), (MI);

- 8. fiscal year (proposed first year of construction), (FY);

- 9. project cost (estimated construction cost in 1000's of dollars), (COST);

- 10 . project work type (five general categories-see below), (WK);

- 11 through 15. project work type dummy variables (coded as a 1 or a 0 for bridge (BR), modernization (MOD), preservation (PRES), safety (SAFE), or miscellaneous (MISC);

- 16 through 19. highway LOI classification dummy variables (coded as a 1 or 0 for district (DIST), interstate (INST), regional (REG), and statewide (STW);

- 20 through 24. ODOT region dummy variables (coded 1 or 0 for regions 1 through 5: R1, R2, R3, R4, and R5);

- 25. county area in square miles (AREA);

- 26. county population for the program year (POP);

- 27. county VMT for the program year, in 1000s of miles (VMT);

- 28. total state highway miles in each county (HWY MI);

- 29. county population density for the program year (persons per square mile) (DENSITY); 
- 30. county VMT per mile of state highway for the program year (VMT/MI);

- 31. county VMT per capita for the program year (VMT/CAP);

- 32. county population growth factor (gain/loss in population from 1978 to 1992 divided by 15) (POPGRW);

- 33 through 37 . dummy variables formed from combining work type with length (coded as the project length for a work type (X.X) or a 0 for bridge miles (BRMI), modernization miles (MODMI), preservation miles (PRESMI), safety miles (SAFEMI), or miscellaneous miles (MISCMI);

- 38. county population density squared (DNSTSQR); and

- 39. county population squared (POPSQR).

A sample printout of the 1988 project dataset is included as Appendix 2.

\section{Project Dataset Analysis Methodology}

The previous runs of simple linear regression were of little importance in analysis of the county datasets, therefore all analyses performed on the project datasets were multiple linear regression. Based upon previous simple regression analysis of the county aggregate dataset, some project level analyses were not performed due to their lack of significance or inconclusive results. Some of these were analyses involved eliminating ODOT region or highway level of importance variables. The multiple regression was performed from the Excel spreadsheets by importing the files into the SPSS, Version 6.0 statistical analysis program; this program was also used to determine correlations amongst the dataset variables.

As with the county datasets, one typical sample program year was used for testing combinations of variables with the multiple regression analysis. The 1988 program was 
used to maintain consistency with the other analyses; this dataset contained 331 samples (projects). Once again project COST was the dependent variable. Regressions were run with numerous variables, not including ones previously eliminated eartier in the county analysis. Analysis efforts focused on the following variables: AREA, POP, POPGROW, POPSQR, DENSITY, VMT, and the dummy variables for work type and LOI (BR, MOD, PRES, SAFE, MISC, DIST, INST, REG, and STWD). Initial regression analysis on the above variables consisted of normal and no - intercept (through the origin) methods; the no - intercept method produced no significant improvements in the analysis, and was subsequently eliminated. Eight regression models were ultimately run, all using the POPGROW, POPSQR, LOI and work type variables, plus the following combinations of other variables: 1.) AREA, POP, DENSITY, and VMT; 2.) AREA, POP and DENSITY; 3.) AREA, DENSITY and VMT; 4.) AREA, POP and VMT; 5.) AREA and POP; 6.) AREA and VMT; 7.) DENSITY and VMT; and 8.) DENSITY.

Analysis of the 1988 project program sample regressions showed no significance for the variables AREA, POPGROW, POPSQR or DENSITY; these variables were not used further in the project analysis. The regression and correlation results for the 1988 project program led to the elimination of the dummy variables in subsequent project dataset regressions. When performing the dummy variable regressions, one in each category (PRES in work type and DIST in LOI) was withheld as the reference variable, to which the others in the same category were compared. The reference dummy variable PRES was used since preservation projects seemed to represent the middle ground for cost of project versus length, while the DIST dummy variable represented the lowest class of highway, therefore most likely receiving the least cost per mile of project. Although the dummy variables were not to be used in subsequent analysis, they did prove useful to corroborate 
the two secondary hypotheses. The first hypothesis concerned work types: MOD and BR projects had more impact than PRES, while SAFE and MISC had less. The second test hypothesis concerned highway LOI types, projects on REG had less impact, while INST and STWD had more impact than work on DIST. The lesser impact of REG projects, even though a higher level of importance, can be explained by the facts that there are fewer regional highway miles than any other class, and that the regional class was created out of the district class when the LOI system originally contained only three classes. In the case of the LOI dummy variable analysis, the initial assumption was also proved by the regression results. The two test hypotheses, one concerning relative ranking of highway LOls and the other the ranking of work types, were carried through to the next round of regressions.

The first regression runs on all five of the project program datasets used COST as the dependent variable, and the following independent variables: POP, VMT, DIST, INST, REG, STWD, BRMI, SAFEMI, PRESMI, MODMI, and MISCMI. The last five variables are collectively called the "WKTYPEMI"variables. The two variables, DIST and PRESMI, were left out of the analyses as the reference variables. These regressions produced very low Rsquared values, ranging from a low of 0.083 for 1992 to a high of 0.230 for 1986 .

The low R-squared values for the above "WKTYPEMl" analyses led to substitution of the five combined "WKTYPEMI" variables with the five work type variables BR, SAFE, PRES, MOD, and MISC, along with the variable MI. Two reference variables were left out, as with the previous regressions one was for LOI (DIST) and the other for work type (PRES). Three regressions, using POP and VMT, singly and in combination, were run for each of the five datasets, once again using COST as the dependent variable. The regressions included the four work type variables, the three highway LOI variables, the mileage variable, and the combinations of VMT and POP. The population model produced 
the best results, and is the project dataset model used hereafter for analysis and discussion. The population regression results for the project dataset are shown in Table VI.

Comparison of the highway LOI coefficients for INST, REG and STWD indicates that in 14 out of 15 cases, projects planned for these types of highways were more costly than projects on district (DIST) highways. Interstate highway projects (INST) were the most costly, followed by statewide (STWD) and regional (REG), with the district highways remaining the reference variable for LOI. This order of cost was consistent with the anticipated cost structure for LOI types, based upon function. Interstate freeways are higher level facilities, and therefore would cost more to construct than the other types. The district highways are almost local roads in many areas, and would consequently have lower traffic volumes, design standards and costs. The one instance of regional highway projects costing less than district, in 1988 , may be attributed to proportionally fewer and lower cost projects in 1988 than other study program years. This cost structure based upon highway $\mathrm{LOI}$ is consistent with the first of the secondary hypotheses of this report. To restate that hypothesis, planned highway construction projects, based upon a level of importance (LOI) system, rank from most to least cost in the following order: interstate (INST), statewide (STWD), regional (REG), and district (DIST). This LOI ranking was also and indicated earlier when the dummy LOI variables were used in the regressions. 
TABLE VI

Project Dataset Multiple Regression Results

\begin{tabular}{|c|c|c|c|c|c|}
\hline $\begin{array}{l}\text { Independent } \\
\text { Variable }\end{array}$ & 1978 & 1982 & 1986 & 1988 & 1992 \\
\hline $\mathrm{N}$ & 401 & 269 & 411 & 330 & 433 \\
\hline R-squared & 0.242 & 0.252 & 0.169 & 0.222 & 0.251 \\
\hline Constant & -1003.732 & -1548.102 & -696.947 & 64.249 & -878.944 \\
\hline $\bar{T}$ & -1.344 & -1.257 & -0.891 & 0.081 & -0.956 \\
\hline $\operatorname{sig} T$ & 0.180 & 0.210 & 0.373 & 0.936 & 0.335 \\
\hline MI & 59.544 & 37.904 & 11.451 & 7.847 & -8.009 \\
\hline$T$ & 0.982 & 0.770 & 0.732 & 0.591 & -0.342 \\
\hline $\operatorname{sig} T$ & 0.327 & 0.442 & 0.465 & 0.555 & 0.733 \\
\hline POP & 0.009 & 0.005 & 0.002 & 0.003 & 0.006 \\
\hline $\bar{T}$ & 5.486 & 3.549 & 1.459 & 2.576 & 2.828 \\
\hline $\operatorname{sig} T$ & 0.000 & 0.001 & 0.145 & 0.011 & 0.005 \\
\hline BR & 1630.236 & 3189.118 & 1604.668 & 987.427 & 872.224 \\
\hline$T$ & 1.786 & 2.413 & 1.859 & 1.093 & 0.863 \\
\hline $\operatorname{sig} T$ & 0.075 & 0.017 & 0.064 & 0.275 & 0.389 \\
\hline MOD & 2413.105 & 3870.403 & 2670.579 & 2756.839 & 5489.383 \\
\hline $\bar{T}$ & 3.909 & 3.444 & 3.831 & 4.080 & 6.682 \\
\hline $\operatorname{sig} T$ & 0.000 & 0.001 & 0.000 & 0.000 & 0.000 \\
\hline MISC & -4459.309 & -2381.139 & -1872.340 & -2018.446 & -2740.613 \\
\hline $\bar{T}$ & -1.912 & -1.104 & -1.823 & -2.120 & -1.390 \\
\hline $\operatorname{sig} T$ & 0.057 & 0.271 & 0.069 & 0.035 & 0.165 \\
\hline SAFE & -889.467 & -427.055 & -603.418 & -926.649 & -2227.600 \\
\hline$T$ & -1.163 & -0.371 & -0.808 & -1.234 & -2.303 \\
\hline $\operatorname{sig} T$ & 0.246 & 0.711 & 0.420 & 0.218 & 0.022 \\
\hline INST & 3599.834 & 4018.721 & 3204.051 & 2122.631 & 6046.815 \\
\hline $\bar{T}$ & 3.993 & 4.480 & 5.462 & 3.484 & 5.728 \\
\hline $\operatorname{sig} T$ & 0.000 & 0.000 & 0.000 & 0.001 & 0.000 \\
\hline REG & 183.503 & 278.491 & 1199.766 & -332.370 & 1114.599 \\
\hline$T$ & 0.232 & 0.289 & 1.480 & -0.440 & 0.965 \\
\hline $\operatorname{sig} T$ & 0.817 & 0.773 & 0.140 & 0.660 & 0.335 \\
\hline STWD & 587.605 & 1302.839 & 1328.307 & 183.737 & 2944.088 \\
\hline & 1.001 & 1.828 & 2.649 & 0.373 & 3.871 \\
\hline Sig I & 0.317 & 0.069 & 0.008 & 0.709 & 0.000 \\
\hline
\end{tabular}

NOTES: Dependent Variable $=$ COST

BOLD data are significant at the five percent level 
The regression results of the population model runs for the five years produced better R-squared values for four out of five years, 1986 excepted; still the R-squared values did not exceed 0.252 . Three of the independent variables, as indicated by the $T$ values shown in Table VI, were significant: POP, MOD, and INST; the last two do not have any relevance to geographic distribution. Examination of Table VI shows the mileage (MI) variable was not significant for any program year, while population (POP) was significant in all years but 1986 . One trend indicated by the decreasing constant for the MI variable is that the investment per mile of highway project has decreased over time, from about $\$ 60$ to $\$ 8$ per mile. The lower T value for the POP variable in 1986 may be due to the close interval between it and the previous plan from 1988. The constant values for the POP variable in these regressions signify that highway investments were projected for areas with larger populations.

An examination of the coefficient values for the work type and LOI independent variables for the program year 1988 is useful to indicate the relative ranking of priorities of highway projects.

These coefficients for highway work types verify the anticipated ranking of costs, with MISC and SAFE lower, and BR and MOD higher than the reference variable PRES. The 1988 coefficients for work type, in the above order, are: $-2018.446 ;-926.649 ; 1.000$ (reference); 987.427 ; and 2756.839. This indicates that modernization projects in 1988 received over $\$ 2700$ per project related to preservation projects receiving $\$ 1$ per project, while miscellaneous projects received over $\$ 2000$ less per project than the reference preservation projects. 1988 coefficients for the work type variables indicate a priority of construction projects, from least to most expensive, as follows: modemization, bridge, preservation, safety, and miscellaneous. The coefficients for these variables in the other 
four programs follow the exact same ranking priority. Modernization (MOD) projects usually entail either new construction or major reconstruction, while bridge (BR) projects are high cost/short length projects; both of these would be more expensive than relatively uncomplicated roadway resurfacing (preservation, PRES) projects. Safety (SAFE) and miscellaneous (MISC) projects usually are low cost projects, being relatively simple jobs such as sign or guardrail installations, frequently spread out along many miles of highway. The regression analysis confirmed the ranking of work types from most to least expensive: MOD, BR, PRES, SAFE, and MISC, thus verifying second of the secondary hypotheses.

The coefficients for level of importance (LOI) for 1988 are, from highest to lowest, as follows: interstate (INST), 2122.631; statewide (STWD), 183.737; district (DIST), 1.000 (reference); and regional (REG), -332.370. The 1988 coefficients differed from the other four program results in that the other four had positive values for regional highways; the different (negative) value for the 1988 REG may have been due to fewer and less expensive projects on the regional highways. The coefficients for 1988 show that for each dollar of district (DIST) highway project spent, the cost for a project on interstate (INST) highways was $\$ 2122$ more, those on statewide highways $\$ 183$ more, and those on regional (REG) \$332 less. Values for the coefficients for the other programs reflected similar trends, with the 1988 REG being the unusual value. Aside from the aberrant value for 1988 noted above, the ranking of projects from most to least expensive by highway level of importance (LOI) is: interstate (INST); statewide (STWD); regional (REG); and district (DIST).

The project level multiple regression results on the project dataset confirmed earlier assumptions on two hypotheses, ranking of projects by work type and highway level of importance, while once again showing population as a significant variable. However, these same regressions, based upon the low R-squared values for all runs, failed to show 
anything conclusive regarding the main hypothesis; therefore it became necessary to run additional analysis on the county dataset.

\section{Revised County Dataset Multiple Regression Analysis}

The final multiple regression analysis was performed on the county datasets. Going back to regressions on the county data was necessary due to the lack of any meaningful geographic correlations with the project dataset regressions. The new county regressions were performed using total cost (TOT\$\$) as the dependent variable, and a selection of independent variables likely to give useful geographic distribution results. The county datasets used some of the same variables as the project dataset, but more were different. Aggregate county data for projects included three LOI categories: primary, secondary and total; and only two work types: modemization and preservation. Combinations of these formed the remainder of the county dataset. Only the variables used in the final set of county regressions which have not been previously described will be explained.

Two regressions for each program year were run using a total of six independent variables in each regression. The two runs differed in the use of either VMT or POP as one of the independent variables, the others being AREA, DENSITY, POPGROW, TOTMI (the total mileage of both primary and secondary highway projects in a program year), and TOTMAX (the total mileage of all highways in a county). The POP runs providing slightly better R-squared values than the VMT runs, and also had greater T values. The POP regression results are summarized in Table VII. 
TABLE VII

County Dataset Multiple Regression Results

\begin{tabular}{|c|c|c|c|c|c|}
\hline $\begin{array}{l}\text { Independent } \\
\text { Variable }\end{array}$ & 1978 & 1982 & 1986 & 1988 & 1992 \\
\hline R-squared & 0.939 & 0.906 & 0.867 & 0.946 & 0.796 \\
\hline $\bar{N}$ & 36 & 36 & 36 & 36 & 36 \\
\hline Constant & -13028.381 & -20780.668 & -16582.975 & -13416.926 & -6414.894 \\
\hline$T$ & -1.427 & -2.624 & -1.860 & -2.901 & 0.493 \\
\hline $\operatorname{sig} T$ & 0.164 & 0.014 & 0.073 & 0.007 & 0.626 \\
\hline$\overline{\text { AREA }}$ & -1.222 & -3.225 & -5.773 & -3.688 & -2.691 \\
\hline$T$ & -0.570 & -1.636 & -2.550 & -3.312 & -0.890 \\
\hline $\operatorname{sig} T$ & 0.573 & 0.113 & 0.016 & 0.003 & 0.381 \\
\hline POP & -0.043 & -0.152 & -0.151 & -0.097 & 0.306 \\
\hline$T$ & -0.495 & -2.108 & -1.846 & -2.349 & 2.955 \\
\hline $\operatorname{sig} T$ & 0.625 & 0.044 & 0.075 & 0.026 & 0.006 \\
\hline DENSITY & 368.917 & 257.668 & 260.787 & 218.613 & 38.596 \\
\hline$T$ & 8.973 & 6.992 & 6.382 & 10.441 & 0.754 \\
\hline $\operatorname{sig} T$ & 0.000 & 0.000 & 0.000 & 0.000 & 0.457 \\
\hline POPGROW & -5040.743 & -1249.970 & -681.479 & -973.521 & 2785.722 \\
\hline$T$ & -1.768 & -0.501 & -0.242 & -0.652 & 0.657 \\
\hline $\operatorname{sig} T$ & 0.088 & 0.620 & 0.811 & 0.520 & 0.517 \\
\hline TOTMI & 135.392 & 427.149 & 29.592 & -1.463 & 56.432 \\
\hline$T$ & 0.966 & 2.639 & 0.391 & -0.039 & 0.678 \\
\hline $\operatorname{sig} T$ & 0.342 & 0.013 & 0.699 & 0.969 & 0.503 \\
\hline TOTMAX & 92.843 & 168.679 & 235.995 & 182.778 & 133.472 \\
\hline$T$ & 1.320 & 2.722 & 3.184 & 5.279 & 1.414 \\
\hline $\operatorname{sig} T$ & 0.197 & 0.011 & 0.004 & 0.000 & 0.168 \\
\hline
\end{tabular}

NOTES: Dependent Variable $=$ TOT\$ $\$$

BOLD data are significant at the five percent level

T values for POP are significant in 1982, 1988 and 1992, while the $T$ values for AREA are significant twice, in 1986 and 1988. Howevs, the highest and most significant of all the independent variables is DENSITY (population divided by area); only in 1992 is it not significant. The data for 1992 is unusual in that the constant values of the POP and POPGROW variables changed from negative to positive; the 1992 data were examined in detail, but no blunders were uncovered. The overall regression results of this set of runs, in 
terms of the R-squared values, was much better than any of the previous runs, either bivariate or multiple linear regression.

The highest absolute values are for the variable DENSITY, followed by TOTMAX and TOTMI. The regression results in Table VII show that, while not very significant in themselves at the project level, the variables POP and AREA (the two variables used to create the DENSITY variable) have the greatest positive influence on the cost of highway projects. A sample regression was run on the 1988 dataset, without DENSITY; the constants and T values for AREA and POP switched from negative to positive, but the Rsquared value was lowered by over 0.100 . Next in importance is the total highway mileage in a county, followed by the total mileage of proposed construction projects; for both these variables, the coefficients are positive, except the negative value for 1988 TOTMI. The combination of the high R-squared values and the significance of the geographic variables DENSITY and TOTMAX in the above regressions signify a meaningful and positive relationship between high expenditure planned highway projects, high concentrations of highway mileage and high concentrations of people.

It is the author's opinion that the results of the final set of county dataset regressions show enough geographic correlation to eliminate the theory of random distribution of highway projects throughout the state of Oregon, but instead show that the planned highway expenditures go where the people and the highways are. This is shown by the DENSITY and TOTMAX variables; these two variable consistently explain variation in planned expenditure by county. The importance of density declined however, from 1978 to 1988, while the importance of total highway mileage increased form 1978 to 1988. However the 1992 program, the first under ISTEA, these two variables fail; the funding appears to be allocated on a per capita basis under this program. This is reflected in the 
coefficient of POP, which changed from a negative value of less than 0.1 to a positive value of over 0.3 , showing an investment of over $\$ 300$ per person. 


\section{SUMMARY AND CONCLUSION OF ANALYSIS}

\section{Summary}

A dataset was created from five ODOT highway construction program documents from 1978 to 1992 ; the dataset contained ten variables from the programs, county data from ODOT and other agencies, and many variables derived from the previous two groups of data. The original dataset was used to create two other, more detailed datasets: the county and project datasets. Both county and project datasets were organized by program year, and then submitted to statistical analysis.

Initial analysis of the county datasets by program, using simple graphical techniques, showed a steady increase in expenditure percentages for modemization projects from 1978 to 1988 , with a corresponding steadily increasing expenditure rate for interstate highway work in the same period. The first change in these patterns occurred in 1986, when expenditures for interstate highway work began to fall; this was due to the beginning of increased state funding for statewide highways. The second pattern change was expenditures for preservation projects increasing in the 1992 program, due to a change in emphasis at the federal level due to ISTEA, from new construction to preservation of existing highway facilities.

Later analyses used project cost, either individual projects or summarized projects by county, as the dependent variable, with from one to a dozen independent variables. The first simple bivariate linear regression analysis on the county dataset was used as a screening process"to limit the number of variable to be evaluated in future analyses, and indicated multiple regression as the next step. The first county dataset multiple linear 
regression analysis was performed on the 1988 program as a test; results indicated the need for multiple regression on the project dataset.

The next round of regression analysis was on the project dataset, and produced slightly better statistical results than the first regressions on the county dataset. The first project dataset analysis confirmed the two secondary hypotheses on highway project ranking. The ranking hypotheses were: 1.) that highway project work types can be ranked, from most to least expensive - as modernization, bridge, preservation, safety and miscellaneous; 2 .) that highway project cost can be ranked from most to least expensive by what type of highway (level of importance) it is - interstate, statewide, regional, and district.

The final multiple regression was run once again on the county dataset. The results of this regression showed a high probability for greater highway project costs in counties with high population densities and high highway mileages, thus validating the primary thesis hypothesis.

\section{Conclusion}

Regression analysis of project and county datasets showed a high correlation between planned highway expenditures and counties with high population densities and large amounts of highway mileage, substantiating the primary hypothesis. Regression analysis also confirmed the project work type ranking hypothesis; the ranking from most to least expensive is: modernization, bridge, preservation, safety, and miscellaneous. The last hypothesis confirmed by the regression was which highways, by level of importance, received the most funding; the ranking, from most expenditures to least is: interstate, statewide, regional, and statewide.

Simple grouping and sorting of project data by county and program led to the following conclusions: 
1.) Modernization work type project expenditures increased from 1978 to 1988.

2.) In 1992, preservation work type expenditures increased at the expense of modernization due to changed federal funding emphasis from modernization to preservation.

3.) Expenditures for interstate highways increased from 1978 to 1988.

4.) Beginning in 1986, expenditures for statewide highways began increasing at the expense of interstate funding, due to increased funding from Oregon to the Access Oregon Highway $(\mathrm{AOH})$ program - all $\mathrm{AOH}$ facilities are statewide highways; by 1992 , statewide highways were receiving more funding than interstate highways.

One problem with the analysis was that use of county population, area and density as proxies for highway demand misses the component of through traffic. Future research on the topic of statewide distribution of planned highway project expenditures might focus on the volume of traffic for the roadway associated with the project. Project specific is average daily traffic (ADT) volumes should yield better results. Project and traffic would have to be related by use of a Geographic Information System (GIS). This would require project level and milepoint limits to relate to ADT locations. 


\section{REFERENCES}

American Association of State Highway and Transportation Officials (AASHTO). Standing Committee on Planning. 1987. Local Finance Survey. [Washington, DC].

Oregon. Department of Transportation (ODOT). Oregon State Highway Division. 1974. Oregon Action Plan For Transportation Planning. [Salem, OR].

Oregon. Department of Transportation. Oregon State Highway Division. 1978. Six-Year Highway Improvement Program Fiscal Years 1979-1984. [Salem, OR].

Oregon. Department of Transportation. Oregon State Highway Division. 1980. Six-Year Highway Improvement Program Fiscal Years 1980-1985. [Salem, OR].

Oregon. Department of Transportation. Oregon State Highway Division. 1982. Six-Year Highway Improvement Program Fiscal Years 1982-1987. [Salem, OR].

Oregon. Department of Transportation. Oregon State Highway Division. 1984. Six-Year Highway Improvement Program Fiscal Years 1984-1989. [Salem, OR].

Oregon. Department of Transportation. Oregon State Highway Division. Planning Section. 1985. Oregon Highway Plan. [Salem, OR].

Oregon. Department of Transportation. Oregon State Highway Division. 1986. Six-Year Highway Improvement Program 1987-1992. [Salem, OR].

Oregon. Department of Transportation. Oregon State Highway Division. 1988. Six-Year Highway Improvement Program 1989-1994. [Salem, OR].

Oregon. Department of Transportation. Oregon State Highway Division. Program Section. 1989. Oregon Action Plan For Transportation 1989. [Salem, OR].

Oregon. Department of Transportation. Oregon State Highway Division. Program Section. 1990. Six-Year Highway Improvement Program 1991-1996. [Salem, OR].

Oregon. Department of Transportation. Oregon State Highway Division. Program Section. 1991a. "Manual for Developing the Six-Year Transportation Improvement Program 1993-1998". [Salem, OR]. Unpublished internal manual.

Oregon. Department of Transportation. Oregon State Highway Division. Planning Section. 1991b. 1991 Oregon Highway Plan. [Salem, OR]. 
Oregon. Department of Transportation. Transportation Development Branch. 1991c. Oregon Mileage Report December 31, 1991. [Salem, OR].

Oregon. Department of Transportation. Transportation Development Branch. 1992a. "1992 County Equity Study". [Salem, OR]. Unpublished internal memorandum.

Oregon. Department of Transportation. 1992b. Oregon Transportation Plan. [Salem, OR].

Oregon. Department of Transportation. 1992c. Six-Year Transportation Improvement Program 1993-1998. [Salem, OR].

Oregon. Department of Transportation. Transportation Development Branch. Roadway Analysis and Mapping Section. 1993a. "Levels of Importance by Category and County ". [Salem, OR]. Unpublished computer summaries of Oregon highways by level of importance, county and mileage.

Oregon. Department of Transportation. Transportation Development Branch. Roadway Analysis and Mapping Section. 1993b. "Ton-Mile Tabulations by County ". [Salem, OR]. Unpublished computer summaries for 1978, 1982, 1986, 1988, and 1992 Vehicle Miles Traveled.

Oregon. Department of Transportation. Transportation Development Branch. Roadway Analysis and Mapping Section. 1993c. [Salem, OR]. Unpublished computer aided drafting and design (CADD) maps.

Oregon. Department of Transportation. 1994. Statewide Transportation Improvement Program 1995-1998. [Salem, OR].

Oregon. Employment Department. Workforce Analysis Section. 1994. "Per Capita Personal Income 1972-1993 ". [Salem, OR]. Unpublished internal personal income summary tabulations.

Oregon. Secretary of State. 1993. 1993-94 Oregon Blue Book. [Salem, OR].

Oregon. State Highway Division (OSHD). 1975. Six-Year Highway Improvement Program January, 1976 to June 30,1981 . [Salem, OR].

Oregon. State Highway Division (OSHD). 1976. Six-Year Highway Improvement Program July 1, 1976 to June 30,1982 . [Salem, OR].

Portland State University. School of Urban and Public Affairs. Center for Population Research and Census. 1989. "Population Estimates for Oregon: 1978-1988 ". [Portland, OR].

Portland State University. School of Urban and Public Affairs. Center for Population Research and Census. 1992. "Population Estimates for Oregon: 1980-1991". [Portland, OR]. 
Portland State University. School of Urban and Public Affairs. Center for Population Research and Census. 1993. "Population Estimates for Oregon, its Counties, and Cities: July 1, 1992". [Portland, OR]. 
APPENDIX A

COUNTY DATASET PRINTOUTS

1978 THROUGH 1992

Source: From varied sources; refer to main thesis text for individual variable sources. 


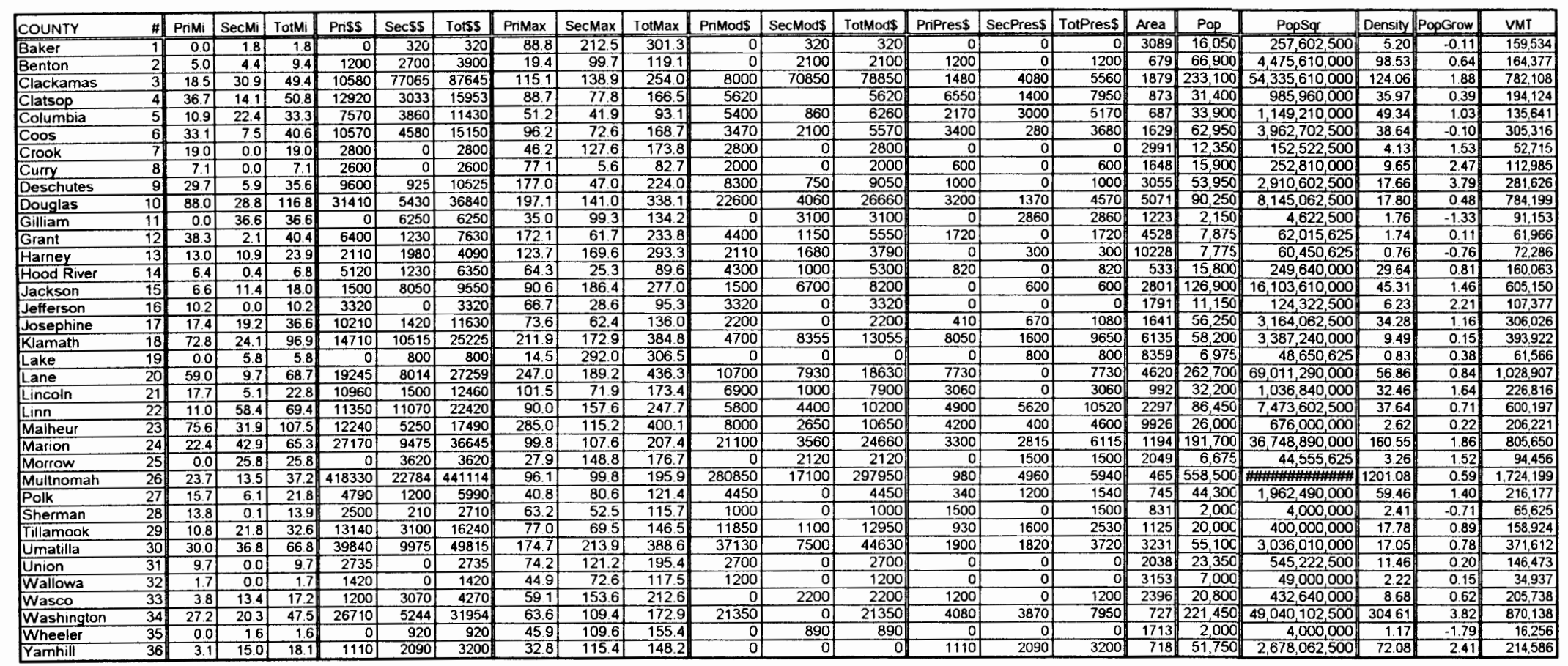









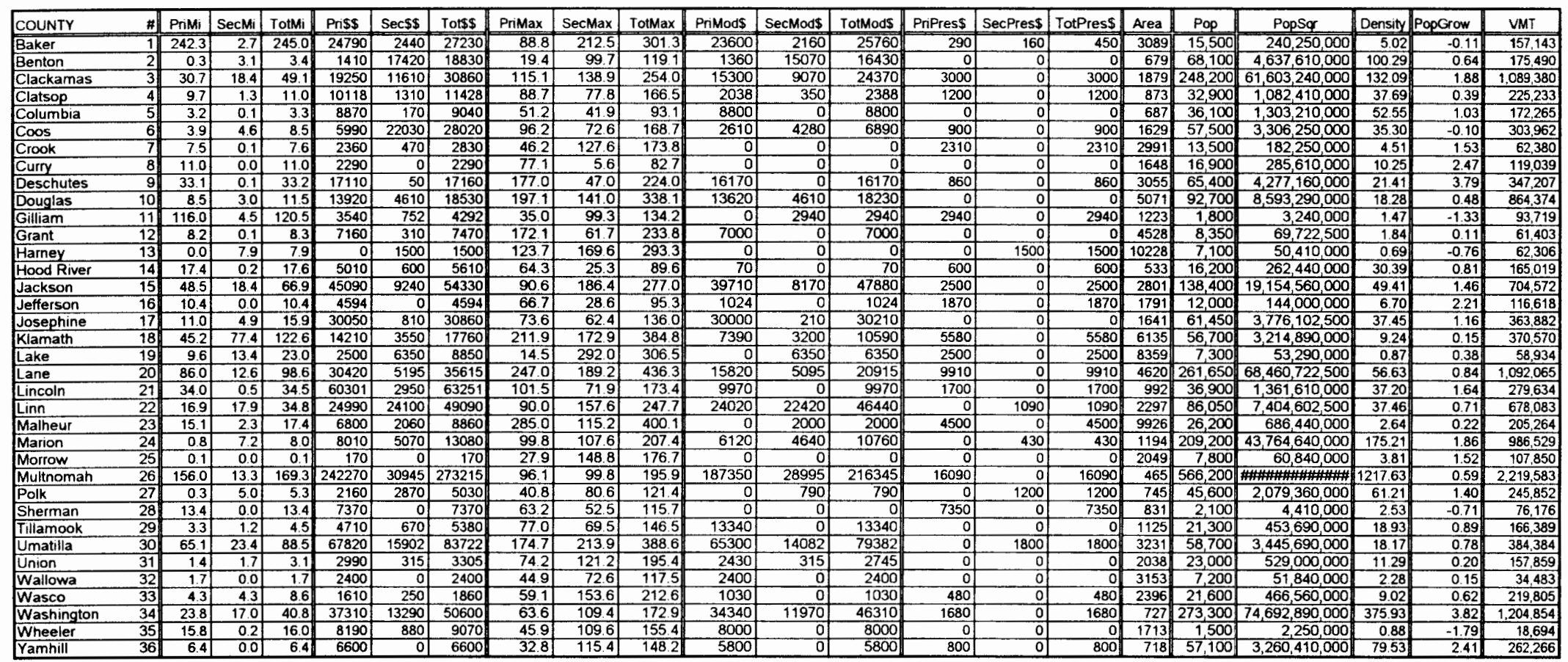




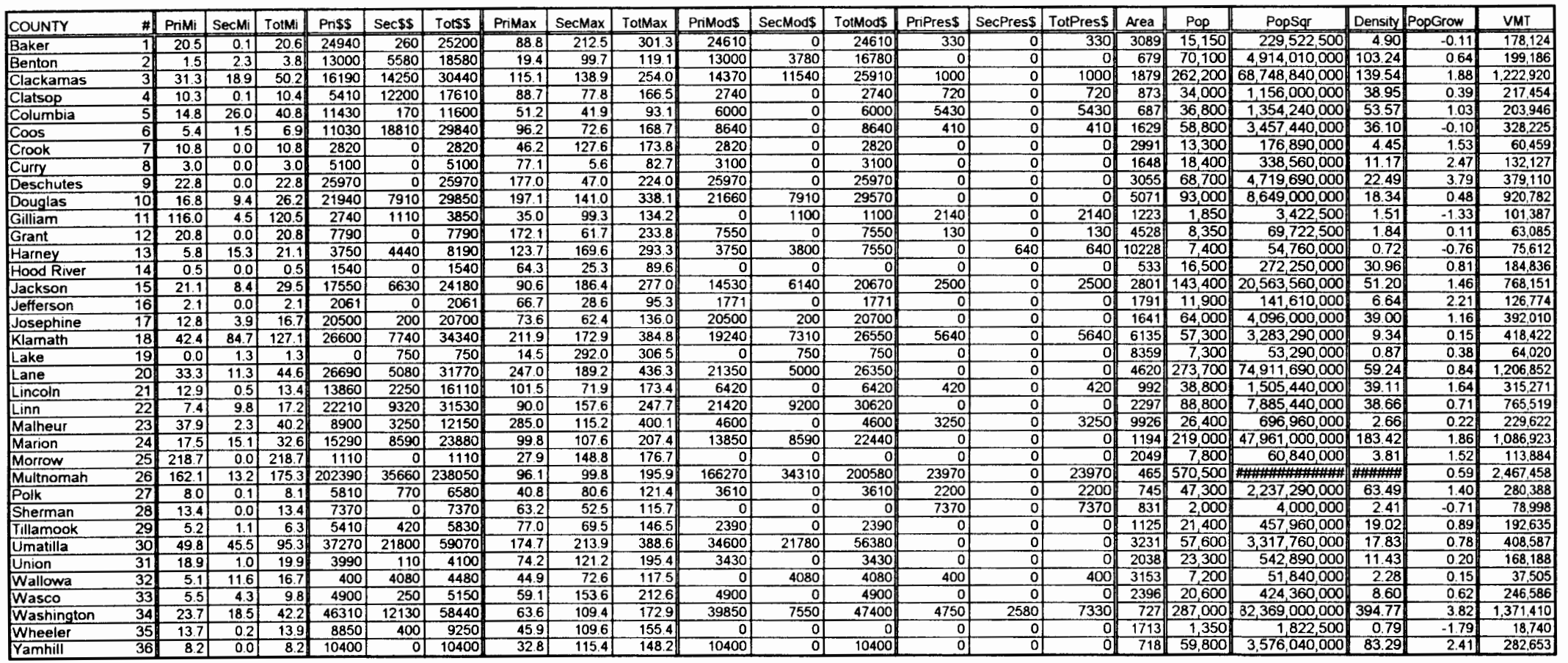




\begin{tabular}{|c|c|c|c|c|c|c|c|c|c|c|c|c|c|c|c|c|c|c|c|c|c|c|}
\hline COUNIY & $\#$ & Primi & SecMi & TotMi & Pris\$ & Sec\$\$ & Tots\$ & Primax & SecMax & Totmax & Primods & SecMod\$ & TotMods & PriPres\$ & SecPres\$ & TotPres\$ & Area & Pop & PopSgr & Density & PopGrow & VMT \\
\hline Baker & 1 & 4.0 & 41.0 & 45.0 & 7530 & 9570 & 17100 & 88.8 & 212.5 & 301.3 & 24610 & & 24610 & 330 & 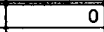 & 330 & 3089 & 15,800 & 249640000 & 5.11 & -0.11 & 227,321 \\
\hline Benton & & 9.9 & 2.0 & 11.9 & 17640 & 8430 & 26070 & 19.4 & 99.7 & 119.1 & 13000 & 3780 & 16780 & 0 & 0 & 0 & 679 & 72,900 & 5314410000 & 10736 & 0.64 & 222,389 \\
\hline Clackamas & 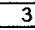 & 22.9 & 37.2 & 60.1 & 26400 & 21550 & 47950 & 115.1 & 138.9 & 254.0 & 14370 & 11540 & 25910 & 1000 & 0 & 1000 & 1879 & 294,500 & 86730250000 & 15673 & 1.88 & $1,410,584$ \\
\hline Clatsop & 4 & 44.5 & 3.6 & 48.1 & 73880 & 530 & 74410 & 88.7 & 77.8 & 166.5 & 2740 & & 2740 & 720 & 0 & 720 & 873 & 33,100 & 1095610000 & 37.92 & 0.39 & 269.382 \\
\hline Columbia & 5 & 13.8 & 1.5 & 15.3 & 43170 & 2190 & 45360 & 51.2 & 41.9 & 93.1 & 6000 & & 6000 & 5430 & 0 & 5430 & 687 & 38,800 & 1505440000 & 56.48 & 1.03 & 199,007 \\
\hline Coos & 6 & 23.3 & 1.3 & 24.6 & 36460 & 3430 & 39890 & 96.2 & 72.6 & 168.7 & 8640 & & 8640 & 410 & 0 & 410 & 1629 & 62,100 & 3856410000 & 38.12 & -0.10 & 375,186 \\
\hline Crook & 7 & $\frac{0.1}{0.1}$ & 0.0 & $\frac{0.1}{0.1}$ & $\frac{1410}{140}$ & 0 & 1410 & 46.2 & 127.6 & 173.8 & 2820 & $\underline{0}$ & 2820 & 0 & 0 & 0 & 2991 & 15,030 & 225000000 & 5.02 & 1.53 & 85,780 \\
\hline Curry & 8 & 8.6 & 0.0 & 8.6 & 15850 & 0 & 15850 & 77.1 & 5.6 & 82.7 & 3100 & 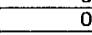 & 3100 & 0 & 0 & (2) & 1648 & 21,430 & 457960000 & 12.99 & 2.47 & 140,289 \\
\hline Deschutes & 9 & 31.5 & 0.0 & 31.5 & 61520 & & 61520 & 177.0 & 47.0 & 2240 & 25970 & & 25970 & $\frac{0}{1}$ & 0 & & \begin{tabular}{|l|}
3055 \\
\end{tabular} & 82,600 & 6822760000 & 27.04 & 3.79 & 488.569 \\
\hline \begin{tabular}{|l|} 
Douglas \\
\end{tabular} & 10 & 31.9 & 30.0 & 61.9 & 95870 & 25140 & 121010 & 197.1 & 141.0 & 338.1 & 21660 & 7910 & 29570 & 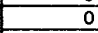 & 0 & & 5071 & 96,320 & 9273690000 & 18.99 & 0.48 & 990,350 \\
\hline Gilliam & 11 & 0.0 & 6.2 & 6.2 & & 5540 & 5540 & 35.0 & 99.3 & 134.2 & & 1100 & 1100 & 2140 & & 2140 & 1223 & 1,750 & 3062500 & 1.43 & -1.33 & 130,912 \\
\hline Grant & 12 & 332.1 & 0.1 & 332.2 & 29310 & 530 & 29840 & 172.1 & 61.7 & 233.8 & 7550 & 0 & 7550 & 130 & & 130 & 4528 & 8,000 & 64000000 & 1.77 & 0.11 & 68.475 \\
\hline & 13 & 69.9 & 0.0 & 69.9 & 8390 & & 8390 & 123.7 & 169.6 & 293.3 & 3750 & 3800 & 7550 & 0 & 640 & 640 & 10228 & 6,9 & 48302500 & 0.68 & -0.76 & 3,380 \\
\hline Jackson & 15 & 44.2 & 9.5 & 53.7 & 91430 & 22440 & 113870 & 90.6 & 186.4 & 277.0 & 14530 & 6140 & 20670 & 2500 & 0 & 2500 & 2801 & 152,900 & 23378410000 & 54.59 & 1.46 & 834,33 \\
\hline Jefferson & & 40.9 & 0.0 & 40.9 & 20890 & & 20390 & 66.7 & 28.6 & 95.3 & 1771 & 0 & 1771 & 0 & 0 & & \begin{tabular}{|l|}
1791 \\
\end{tabular} & 14,630 & 213160000 & 8.15 & 2.21 & 147.740 \\
\hline Josephine & 17 & 29.5 & 3.6 & 33.1 & 14440 & 7380 & 21820 & 736 & 62.4 & 136.0 & 20500 & 200 & 20700 & 0 & 0 & & 1641 & 65,420 & 4277160000 & 39.85 & 1.16 & 419.092 \\
\hline Klamath & 18 & 30.2 & 40.8 & 71.0 & 39910 & 7360 & 47270 & 211.9 & 172.9 & 384.8 & 19240 & 7310 & 26550 & 5640 & 0 & 5640 & 6135 & $59,4 \overline{0}$ & 3528360000 & 9.68 & 0.15 & 456,110 \\
\hline Lake & 19 & 0.0 & 10.8 & 10.8 & & 7430 & 7430 & 14.5 & 292.0 & 306.5 & & 750 & 750 & 0 & 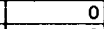 & & 8359 & 7,350 & 54022500 & 0.88 & 0.38 & 79.081 \\
\hline Lane & 70 & 55.0 & 13.8 & 68.8 & 110260 & 46900 & 157160 & 247.0 & 189.2 & 436.3 & 21350 & 5000 & 26350 & & & & 4620 & 293,700 & 86259690000 & 63.57 & 0.84 & $1,308,984$ \\
\hline Lincoln & 21 & 10.7 & 6.7 & 17.4 & 24320 & 1790 & 26110 & 101.5 & 71.9 & 173.4 & 6420 & & 6420 & 420 & 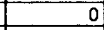 & 420 & 992 & 39,600 & 1568160000 & 39.92 & 1.64 & 327.941 \\
\hline Linn & 20 & 20.6 & 27.3 & 47.9 & 19260 & 18560 & 37820 & 90.0 & 157.6 & 247.7 & 21420 & 9200 & 30620 & 0 & 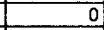 & & 2297 & 95 & 9025000000 & 41.36 & 0.71 & 852.050 \\
\hline Malheur & & 101.1 & & 101.1 & 23150 & & 23150 & 285.0 & 115.2 & 4001 & 4600 & & 4600 & 3250 & & 3250 & 9926 & 26,800 & 718240000 & 2.70 & 0.22 & 274,466 \\
\hline Marion & 24 & 46.0 & 7.4 & 53.4 & 114090 & 5620 & 119710 & 99.8 & 107.6 & 207.4 & 13850 & 8590 & 22440 & & & & 1194 & 241,500 & 58322250000 & 202.26 & 186 & $1,220,420$ \\
\hline Morrow & & 0.0 & 0.1 & 0.1 & & 360 & 360 & 27.9 & 148.8 & 176.7 & & & & & 0 & & 2049 & 8,100 & 65610000 & 3.95 & 1.52 & 131,692 \\
\hline Multnom & & 103.9 & 6.3 & 110.2 & 249390 & 6780 & 256170 & 96.1 & 99.8 & 195.9 & 166270 & 34310 & 200580 & 23970 & & 23970 & 465 & 605,000 & $3.66025 \mathrm{E}+11$ & 1301.08 & 0.59 & 2.725 .186 \\
\hline & & 17.0 & 18.5 & 35.5 & 13730 & 11160 & 24890 & 40.8 & 80.6 & 121.4 & 3610 & & 3610 & 2200 & & 2200 & 745 & 53,000 & 2809000000 & 71.14 & 1.40 & 318,276 \\
\hline Sherma & 28 & 0.0 & 0.0 & 0.0 & & 0 & & 63.2 & 52.5 & 115.7 & & c & & 7370 & & 7370 & 831 & 1800 & 3240000 & 2.17 & -071 & 95044 \\
\hline natilla & 30 & 149.3 & 12.3 & 161.6 & 38600 & 5010 & 43610 & 174.7 & 213.9 & 38 & 34600 & 21780 & 56380 & 0 & 0 & I & 3231 & 61,1 & 3733210000 & 18.91 & 0.78 & 493.251 \\
\hline Union & 31 & 28.3 & 2.9 & 31.2 & 34180 & 3710 & 37890 & 74.2 & 121.2 & 195.4 & 3430 & & 34 & 0 & 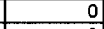 & 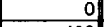 & 2038 & 24,050 & 576000000 & 11.78 & 0.20 & 217,382 \\
\hline wa & 32 & 6.9 & 01 & 10 & 8320 & 640 & 8960 & 44.9 & 72.6 & 117.5 & 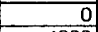 & 4080 & 4080 & 400 & 0 & 400 & 3153 & 7 & 511 & 2.27 & 0.15 & 46,371 \\
\hline & 33 & 47.7 & 97 & 57.4 & 45290 & 1060 & 46350 & 5.1 & 153.6 & 212 & 4900 & 0 & 4000 & 0 & 0 & 4 & 2396 & 22, & 5107 & 9.43 & 62 & 278,641 \\
\hline Washington & 34 & 80.2 & 22.3 & 102.5 & 153370 & 33240 & 186610 & 63.6 & 109.4 & & 39850 & 7550 & 47400 & 4750 & 2580 & 7330 & 727 & 340, & 1.15 & 467.68 & 3.04 & $1,458,210$ \\
\hline Wheeler & 35 & 1.8 & 19.1 & 20.9 & 1190 & 2320 & 3510 & 45.9 & 109.6 & 15 & 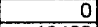 & 0 & O & 0 & & & 1713 & 1,500 & 00 & 0.88 & -1.79 & 20.849 \\
\hline Yamnil & & 7.5 & 18.6 & & & 75 & 18090 & 32.8 & 115.4 & & 1040 & & 104 & & & & 718 & 69. & 4788640000 & 96.38 & 2.41 & 321.865 \\
\hline
\end{tabular}




\section{APPENDIX B}

SAMPLE PROJECT DATASET, 1988

Source: From varied sources; refer to main thesis text for individual variable sources. 


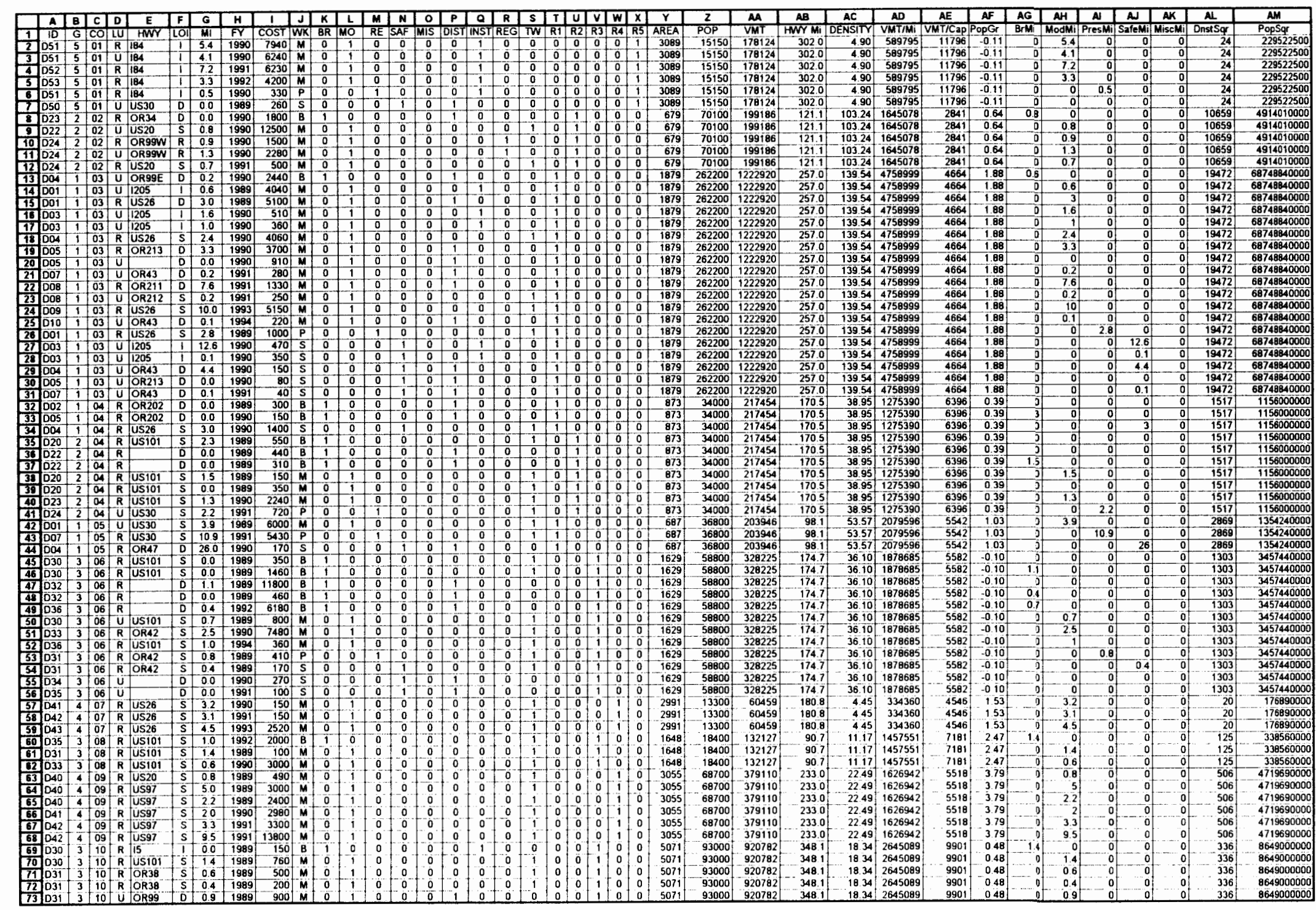




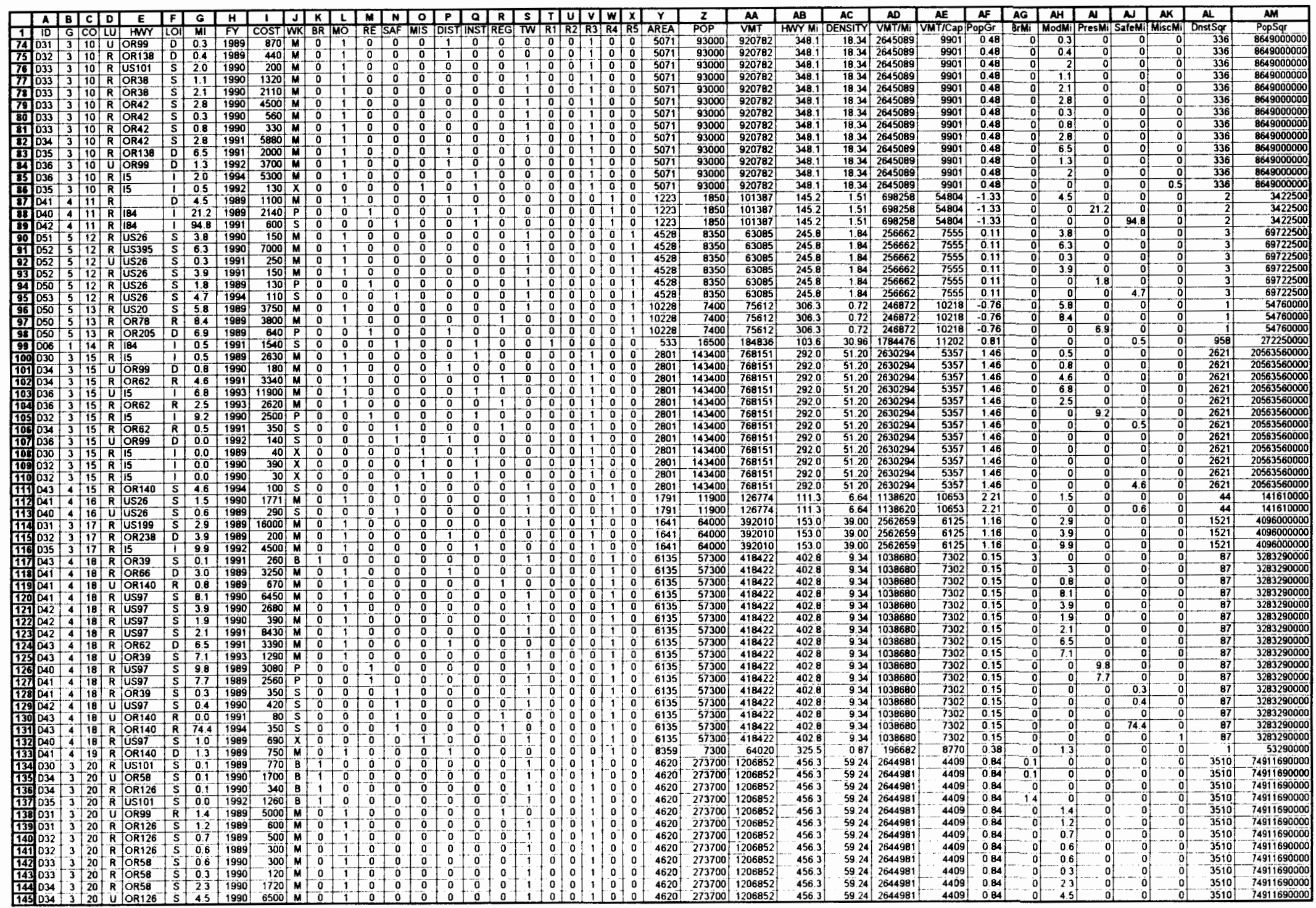




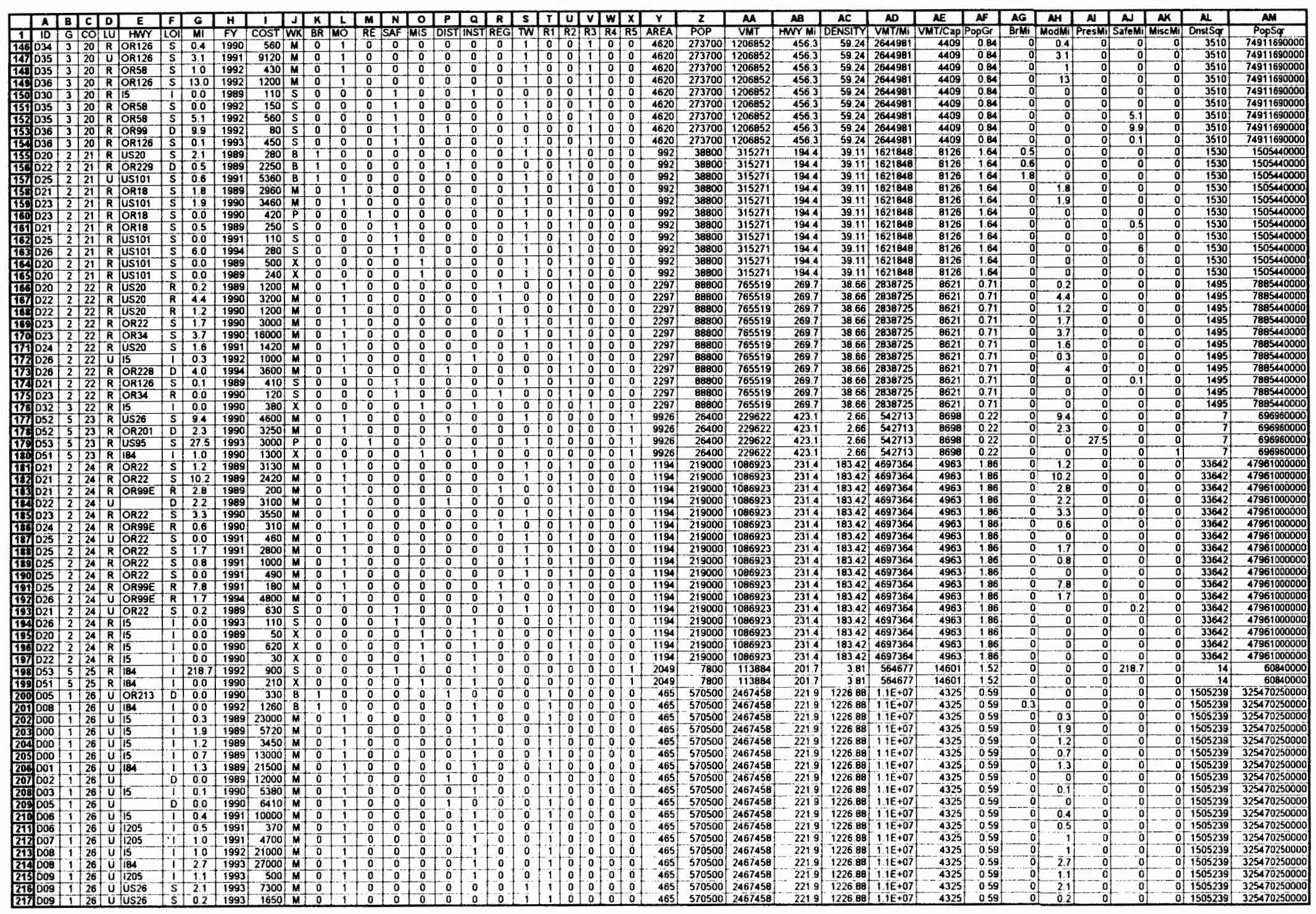




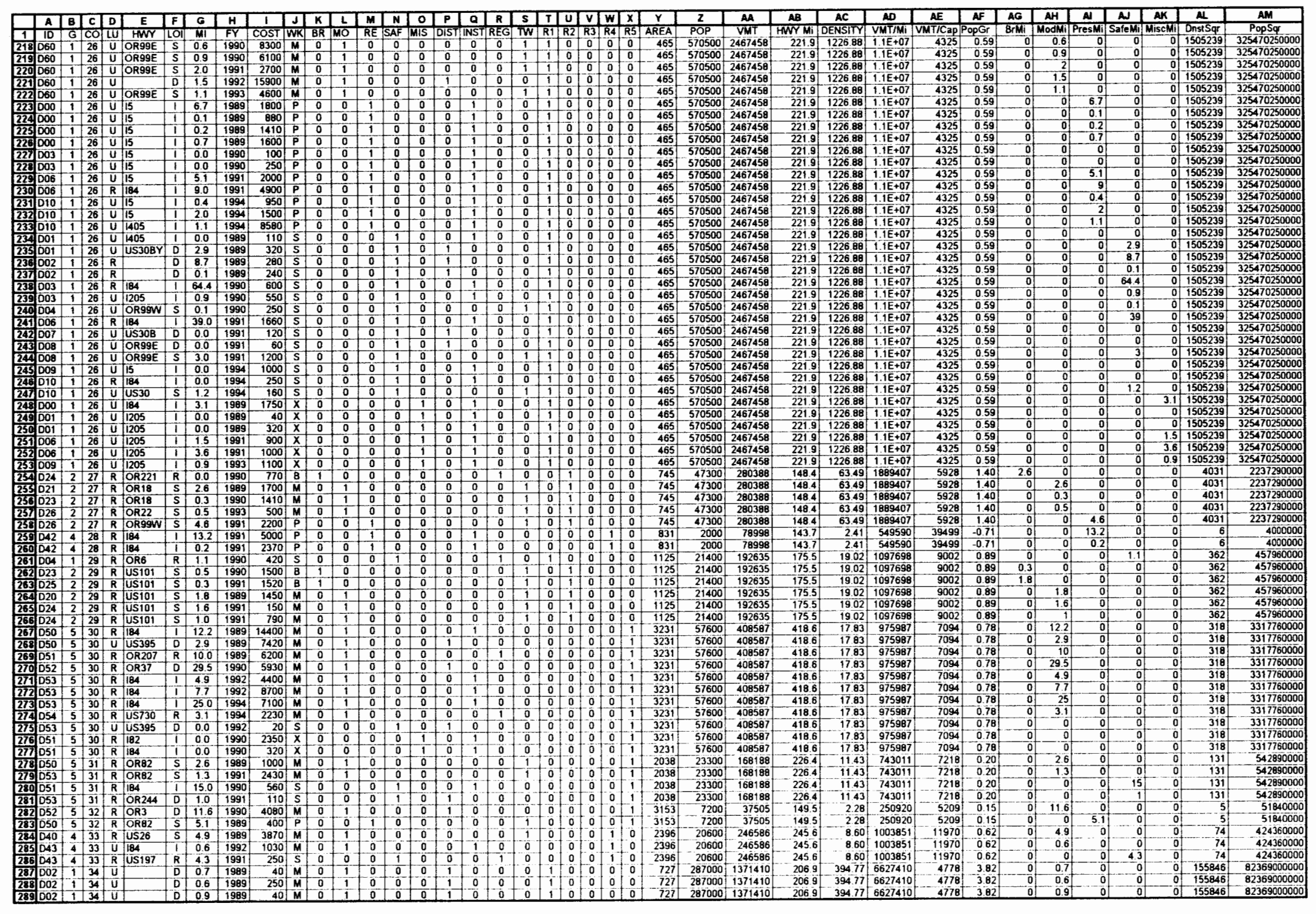




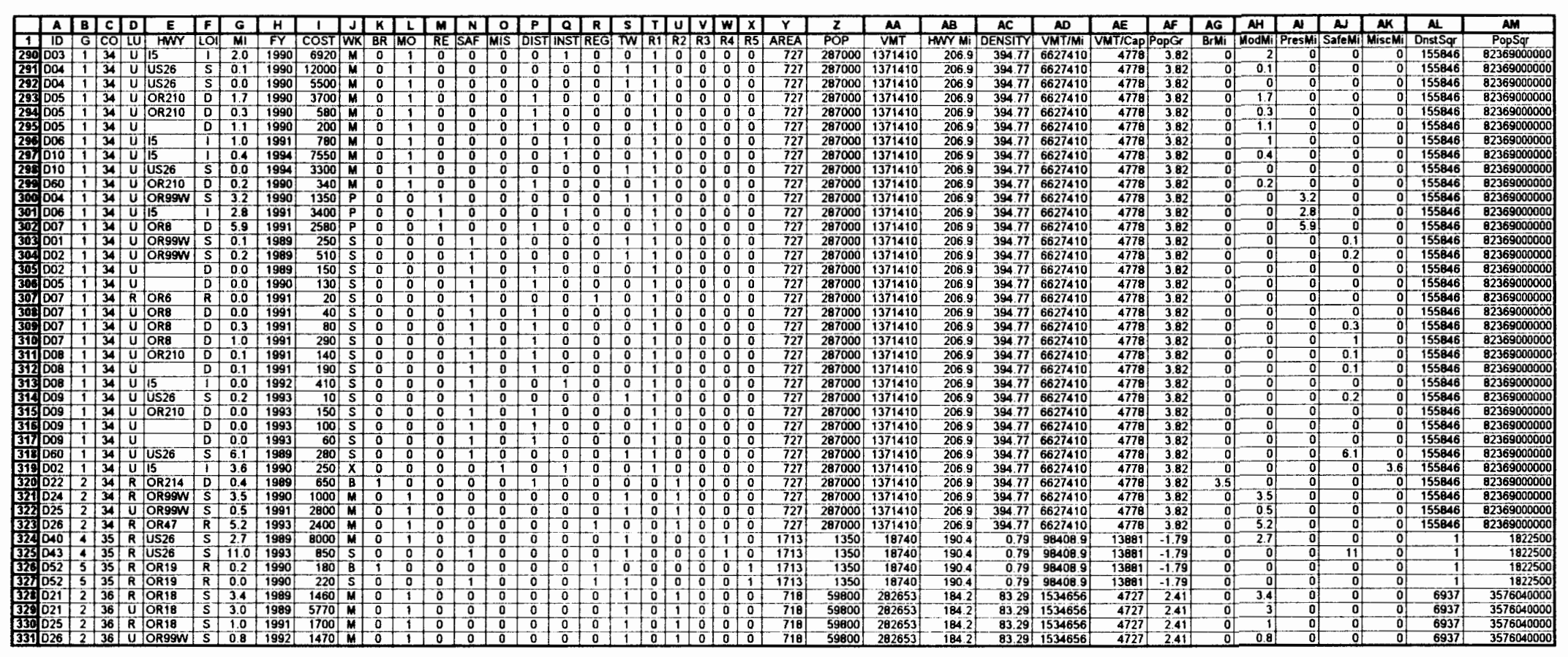

